\title{
A perspectiva linear e o espírito ocidental: a objetivação do subjetivo
}

\author{
Texto Original:
}

Samuel Y. Edgerton, Jr.

Professor de história da arte, da Williams College, Williamstown, MA.

Tradução:

\author{
Prof. Silvio Dias | Profa. Dra. Maíra M. Martins | Prof. Dr. Antonio Sena \\ Professores do Departamento de Arquitetura e Urbanismo, PUC-Rio. \\ Contatos: silviodias@puc-rio.br | antoniosena@puc-rio.br|maira_martins@puc-rio.br
}

Este artigo foi publicado originalmente, em francês, na Revista Cultures, volume III, número 3 de 1976, pela editora Presses de l'Unesco et la Baconniere.

Como explicar a ascensão repentina que transformou o Ocidente no senhor de todo o mundo depois do século XVI? Como explicar que a China e o Islã, duas civilizaçôes que foram muito mais além do que a Europa nos campos técnico e científico durante a maior parte da Idade Média, haviam ficado tão aquém do Renascimento Europeu? Essas são questóes que por muito tempo intrigaram historiadores, filósofos e políticos. O humanista Joseph Needham investigou o problema no último volume de sua obra monumental, Science and Civilization in China (Cambridge, Reino Unido, 1971), no qual ele fala, em todas as páginas da imaginação notável que os chineses já demonstravam no momento em que os povos ocidentais ainda estavam definhando na escuridão da Idade Média. Por que razão toda essa atividade precoce da China (e do Islã) se encerra, no mesmo momento em que o jovem Ocidente avança, justamente numa era de genuína descoberta e revolução científica?

Examinando o grande livro de Needham e refletindo sobre todos os exemplos que ele usa para demonstrar a superioridade inicial da tecnologia e da ciência chinesas naquela época, deparamos com um fato que até agora não havia nos chamado a atenção: nenhuma das representaçôes gráficas chinesas é desenhada em perspectiva linear (Figura 1). Nenhum dos instrumentos científicos e mecânicos incrivelmente complexos era representado da maneira que nos parece normal hoje e que chamamos de "realista". $\mathrm{Na}$ arte chinesa, por exemplo, as linhas paralelas que delimitam as superfícies nunca são representadas, ilusoriamente, convergentes, do modo que "na realidade" elas possam nos parecer. Objetos distantes nunca são representados proporcionalmente menores do que objetos mais próximos, como a "realidade" que em fotografias ou em pinturas renascentistas nos transmitem a sensação a profundidade.

É estranho! Apesar de toda a sua precocidade científica, os chineses (ou mesmo os árabes) nunca perceberam, nos áureos tempos de seu apogeu, a "realidade científica" da perspectiva linear. "É de se perguntar como os artesãos chineses puderam construir instrumentos de determinado tamanho ou serem capazes 

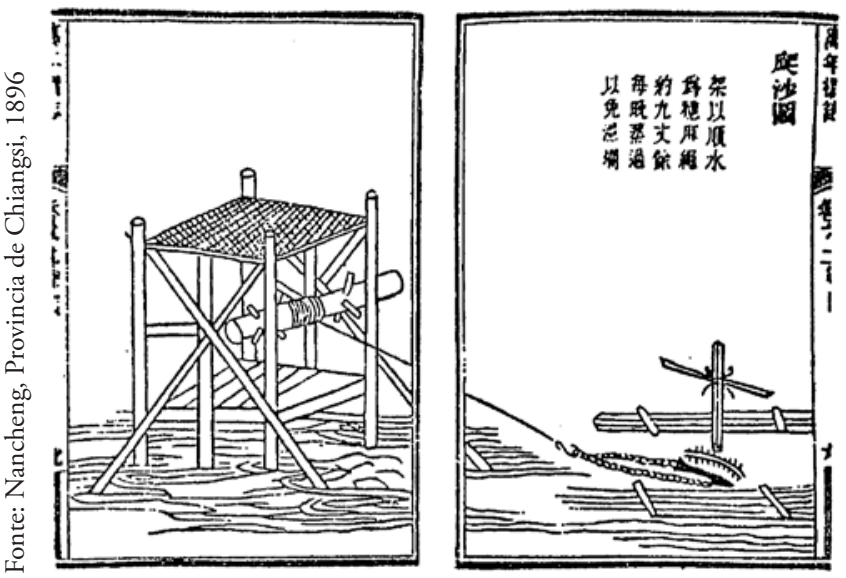

Figura 1: Desenho de uma draga extraido do Tratado Wan-nien Chhiao Chih, por Hsieh Kan-Thang (Nancheng, Provincia de Chiangsi, 1896)

de trabalhar de acordo com tais desenhos "primitivos”. De fato, chegamos à conclusão de que a perspectiva linear era uma noçáo exclusivamente ocidental. Nenhum artista, qualquer que fosse a civilização a que pertencesse, jamais chegou a esse conceito sem ter sido direta ou indiretamente influenciado pelo Renascimento italiano. Além disso, a perspectiva linear apareceu no Renascimento justamente quando o Ocidente começava a superar a China e o Islã nos campos científicos e técnicos. Embora Needham tenha percebido a falta de perspectiva cônica na arte chinesa, ele não sugeriu nenhuma conexão entre essa descoberta e o fato de que a revolução científica não tenha se originado na China ${ }^{2}$.

É possível que uma simples questão de arte - essa fantasia que só pode ser permitida depois de se ter resolvido as questóes verdadeiramente vitais da existência - poderia ter desempenhado um papel decisivo no que é "realmente importante" em meio às rivalidades e divisóes do mundo de hoje? O teórico da arte que sou, no entanto, está ciente de que, assim como a vida engendra arte, a arte pode gerar vida. $\mathrm{O}$ que eu estou argumentando, na verdade, é que o surgimento da perspectiva linear no Ocidente teve profundas conseqüências para o "mundo real". A perspectiva não apenas retratou a "realidade", mas criou uma nova concepção dessa "realidade", ao mesmo tempo em que dava a possibilidade de dominá-la. Ela, sem dúvida, preparou o Ocidente para entrar na era das descobertas no final do século XV. Por outro lado, a falta de perspectiva na arte chinesa e islâmica pode ter sido um dos principais fatores que impediram essas civilizaçóes de iniciar, mais cedo, sua própria revolução científica.

\section{Convençóes no Oriente e Ocidente}

Vamos primeiro voltar ao tempo em que a China; o Islã e o Ocidente Cristão dividiam igualmente as riquezas do mundo. Vamos tomar uma data por volta de 1200 e escolher aleatoriamente três representaçôes gráficas da China, do mundo árabe e da Europa Ocidental (Figuras 2, 3, 4). Naquela época, como as Cruzadas no mundo árabe e a viagem de Marco Polo à China mostrariam, o Ocidente estava um pouco atrás do Oriente no campo científico e tecnológico. No entanto, examinando cada uma das obras, observamos, apesar de algumas diferenças óbvias de estilo, uma analogia notável na forma como cada artista tentou representar os objetos de uma maneira "realista". Nenhum deles conhecia a perspectiva linear e ainda assim todos usavam convençôes quase idênticas para dar a ilusão de objetos tridimensionais colocados no espaço. Móveis, mesas por exemplo, são sempre representados em ângulo com a parte mais importante - o topo - exagerada e distorcida. Os prédios que formam o fundo da pintura são planos e geralmente 
têm mais faces do que se poderia ver logicamente de um determinado ponto. Os três artistas assumiram que o espectador reconheceria automaticamente os objetos na parte inferior da mesa, tão próximos uns dos outros quanto os objetos mais afastados, embora seu tamanho fosse o mesmo.

Que conclusões podem ser tiradas dessas coincidências? Não poderíamos dizer que eles testemunharam a mesma concepção de vida e arte? É possível ter havido o que poderia ser chamado de "conjunto medieval de concepçôes", bastante estranho à visão de mundo ocidental de hoje, porém mais ou menos compartilhado na época por todos os povos pertencentes às três grandes civilizaçôes das quais estamos tratando? Podemos pelo menos afirmar que essas convenções pictóricas, diante da perspectiva, estão ligadas a um processo de estruturação do qual toda inteligência humana tem uma vaga concepção. Em algum lugar do espírito humano, há uma relação inata entre a percepção visual do mundo fenomenológico e as formas essenciais que possibilitam representá-lo nas imagens. Esta ideia não tem nada a ver com perspectiva linear. Convençôes similares também são encontradas em todas as manifestaçóes artísticas estranhas ao Ocidente, desde as pinturas rupestres executados nas cavernas pelos homens de Cro-Magnon, passando pelas pinturas das tumbas egípcias, até as pinturas tribais, que hoje chamamos de primitivas. Elas também são encontrados na arte das crianças, até que estas venham adquirir, ao tornarem-se adultas, a cultura da perspectiva.

O que é particular sobre a perspectiva linear, é bom que se repita, é que esta não é uma noção inata, ela deve sempre ser aprendida. Embora a ciência moder- na argumente que a perspectiva é uma aproximação geométrica da projeção física dos raios luminosos aos olhos, nada prova, a priori, a existência de um meca-

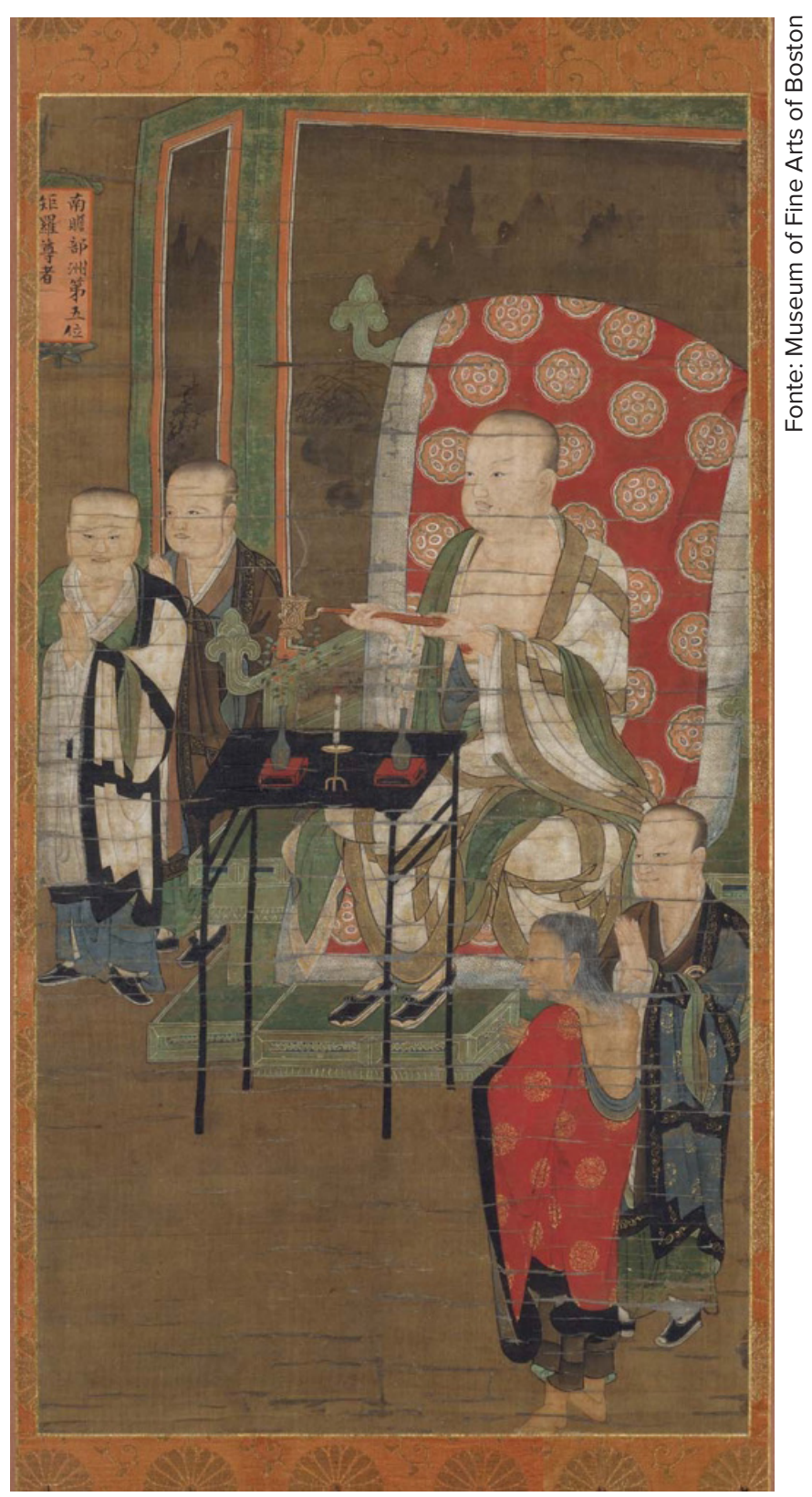

Figura 2: Pintura Chinesa Dinastia Song (960 a 1279). O quinto Rakan segurando um incensário Lu Xinzhong. 


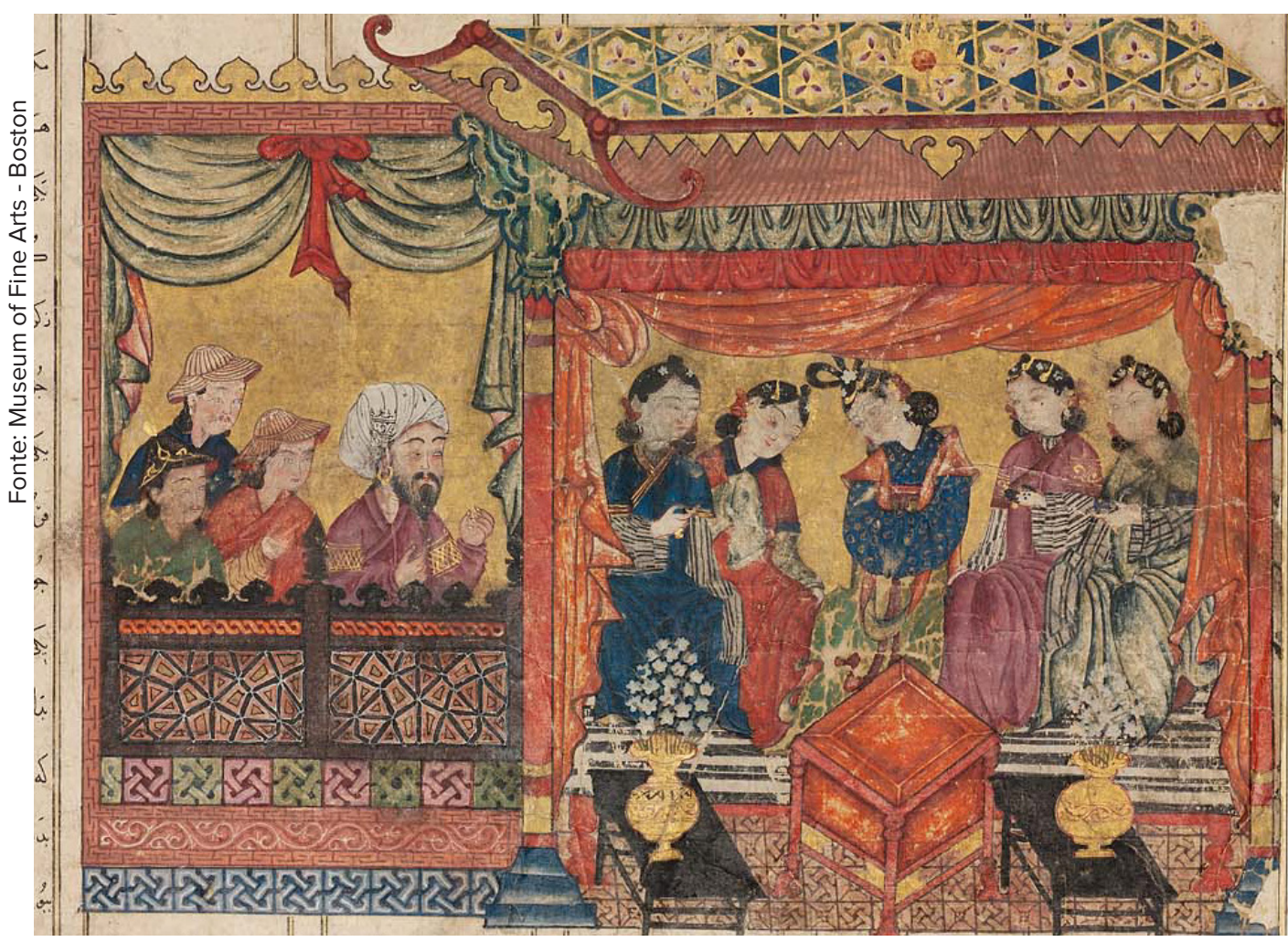

Figura 2:

Pintura Islâmica do fim do século XIII

"Shahnama" de

Firdawsi: Mihran Sitad escolhendo uma das cinco filhas do Khagan (Imperador)

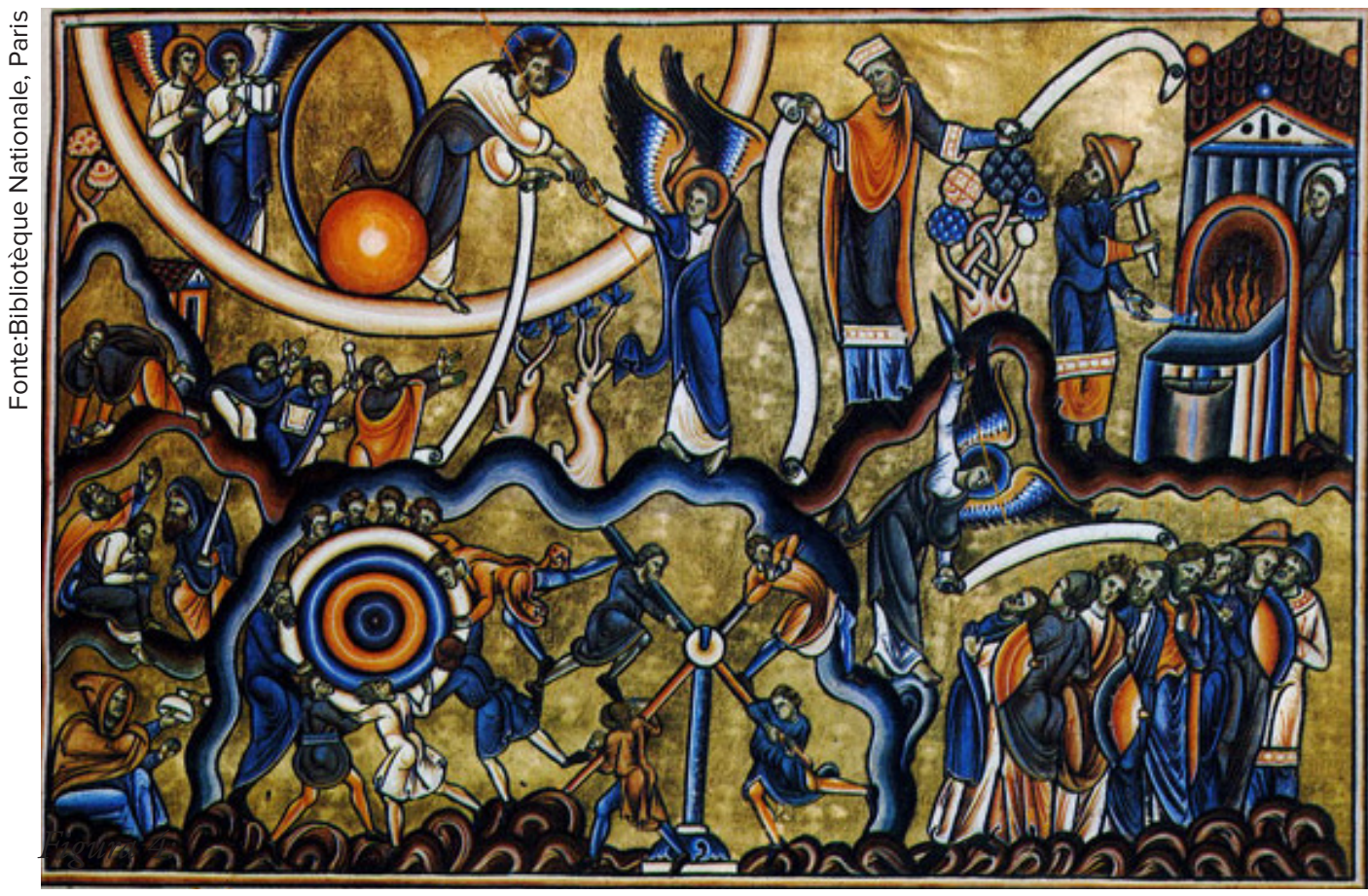

Figura 3:

Pintura Ocidental de cerca de 1200.

Salmo XI,

Psaultier de Canterbury.

Revista online do Departamento de Arquitetura e Urbanismo da Pontifícia Universidade Católica -

Puc-Rio - Rio de Janeiro Brasil

Ano 3 - N5 - ISSN 2446-7340 
nismo na mente, que permita a transferência intuitiva da imagem em perspectiva para sua representação gráfica. Aqueles que pertencem a civilizaçôes estranhas à tradição ocidental, muitas vezes acham difícil, à primeira vista, "visualizar" as representaçôes em perspectiva. Mesmo as fotografias, inventadas para reproduzir mecanicamente o fenômeno da perspectiva renascentista, não são instantaneamente reconhecidas como representações "realistas" por certos povos, ditos, "primitivos".

\section{A “janela”, perspectiva intuitiva}

Por que, então, a civilização cristã ocidental abandonou um sistema de comunicação de imagens tâo facilmente compreendido em todo o mundo em favor de uma perspectiva linear tão difícil de aprender? Por que esse fenômeno só ocorre no Ocidente? Essas são questôes muito difíceis de lidar, especialmente porque estão ligadas a uma evolução mais dramática do equilíbrio de poder entre as três civilizaçóes. Tomemos mais três imagens, oriundas da China, do mundo árabe e do Ocidente, desta vez por volta de 1300 (Figuras 5, 6, 7). Os dois primeiros mostram pouca mudança em relação aos anteriores. Obviamente, os artistas chineses e árabes não procuraram aperfeiçoar seu "realismo" atacando convençôes pictóricas de reconhecido valor. $\mathrm{O}$ que certamente não foi o caso do trabalho ocidental, como se vê na obra do pintor italiano Giotto di Bondone. Contudo, ainda não devemos atribuir a Giotto o conhecimento da perspectiva cônica. A "redescoberta" disso ainda aguardaria por mais de um século. No entanto, notamos nesse quadro, que o artista está experimentando todo um novo vocabulário de formas que representam a terceira dimensão. Ele deliberadamente escolheu um contexto arquitetônico complexo que o força a encontrar no- vas soluçôes, como o tour de force que representa o anjo entrando pela janela da direita. (Figura 7)

Por outro lado, a diferença fundamental entre a ilustração ocidental e a oriental não reside tanto nos

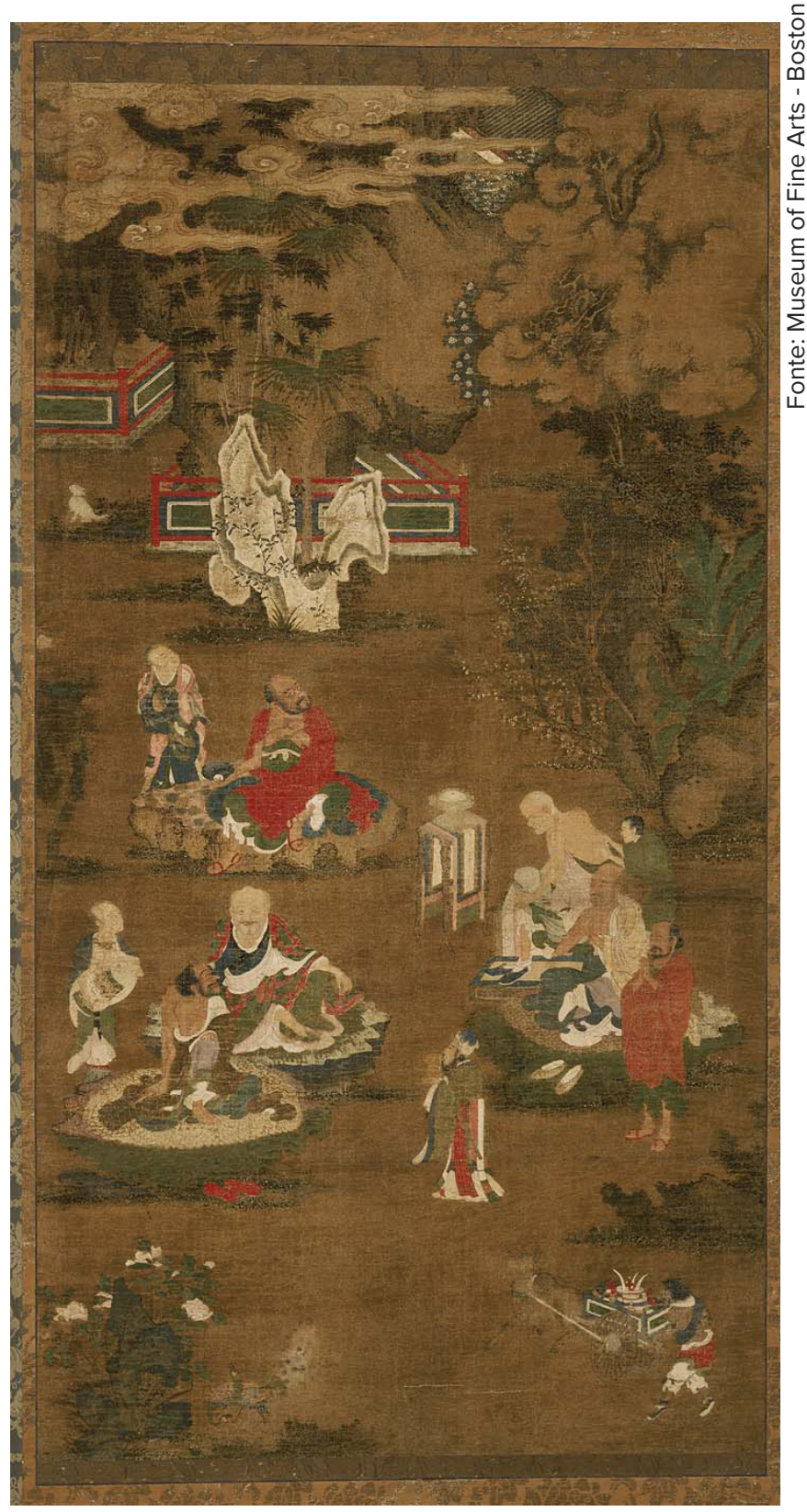

Figura 5:

Pintura chinesa da Dinastia Yuan, 1260 - 1368

Cinco Rakans seus serviçais e um dragão num jardim. 


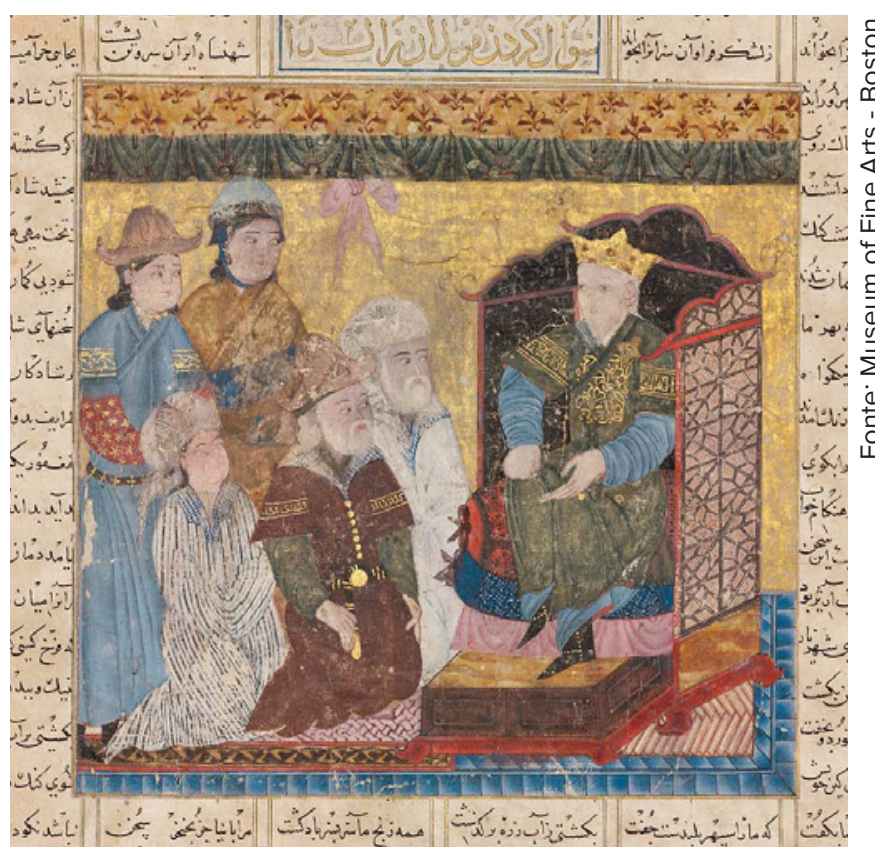

Figura 6: Pintura islâmica de cerca de 1310. Página de um manuscrito Shahnama.

detalhes quanto na concepção geral do quadro. $\mathrm{O}$ artista ocidental considera sua pintura não como uma superfície decorada, mas como uma "janela", um "buraco na parede" (observe como Giotto pinta cuidadosamente uma falsa moldura ao redor da cena que ele compóe) através do qual o espectador deve se imaginar assistindo ao evento descrito. Esta é uma noção que não chegou ao pintor chinês ou ao árabe. Embora os chineses costumassem descrever os volumes no espaço com uma linguagem relativamente convincente (mesmo comparada à perspectiva moderna), o artista chinês sempre considerou a imagem como parte integrante da superfície plana na qual ele inseria sua maravilhosa caligrafia. A pintura Chinesa é uma ruptura da contemplação e das passagens literárias, mas nunca um "buraco na parede" isolado em

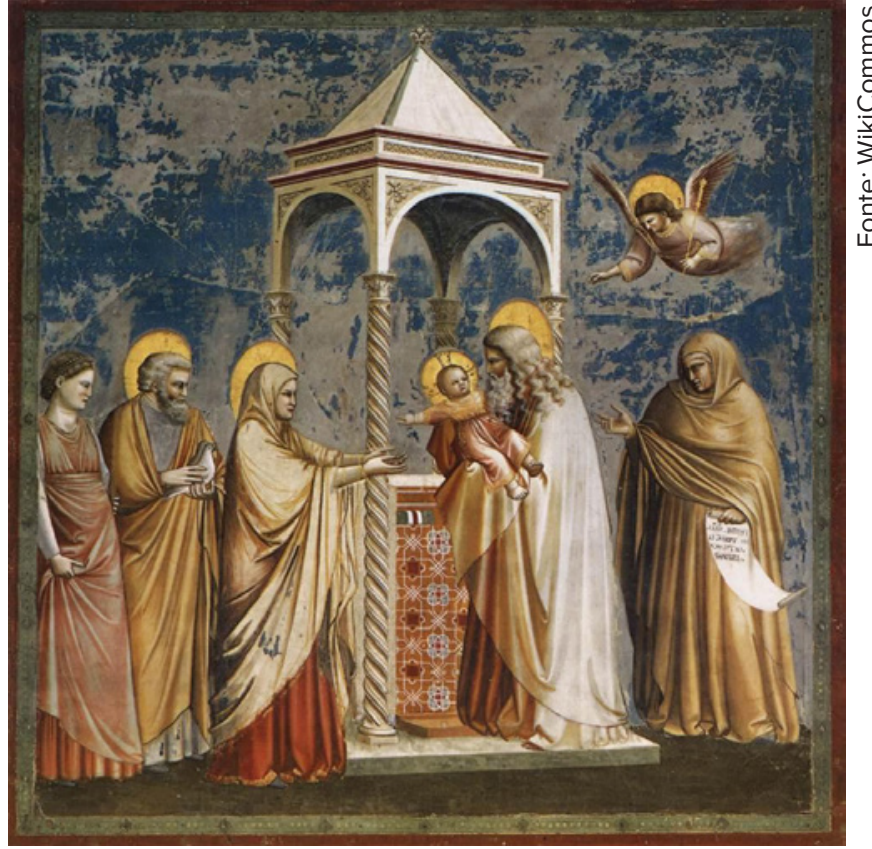

Figura 7: Pintura ocidental de 1305. Giotto, Apresentação de Cristo no Templo detalhe dos afrescos da Cappella degli Scrovegni, Pádua.

si. Os artistas ocidentais, por outro lado, começaram a separar suas imagens de qualquer texto relacionado. Se inscriçóes literárias tivessem de aparecer no quadro, elas apareceriam frequentemente em faixas ou em outros objetos na pintura e, consequentemente, fazendo parte da mesma ilusão geral. Essa nova concepção de "janela"demandaria, tanto por parte do artista quanto do espectador, exigências sem precedentes na China ou no mundo árabe.

Uma abordagem pessoal talvez possa dar uma idéia da importância dessa evolução, não apenas no campo da pintura em si, mas no da psicologia de sua percepçáo. Tente se lembrar daquele momento distante no passado, no maternal ou jardim de infância, quando você fez sua primeira pintura. $\mathrm{O}$ grande papel branco e virgem no cavalete e todos aqueles po- 
tes atraentes cheios de cores! Não era claro, naquele momento, o que uma pintura significava para você, mas, com certeza, não foi uma "janela” (na verdade, a 'janela' pintada pode ser entendida em um outro tipo de exercício, no qual o professor pede ao aluno que desenhe sobre uma placa de vidro, o que ele vê do outro lado). Em todo o caso, você estava inteiramente imerso nessa primeira pintura em papel. Foi no espaço circundante que você aplicou cores e não um espaço em transparência. Foi, em vez de uma representação fotográfica, um mundo que substituiu o outro e no qual você poderia derramar seus sonhos, suas certezas e suas inquietudes. Uma faixa azul no topo era suficiente para representar o Céu - porque todo mundo sabe o que a pessoa a vê ao levantar a cabeça. Para o chão, era o oposto: uma faixa verde resolveria. Quanto à sua casa, você queria mostrar todos os lados de uma só vez. Era natural já que você sabia que tinha quatro paredes em torno das quais todas as brincadeiras aconteciam.

Que surpresa, então, chegar na escola para aprender a ler e escrever, e encontrá-la sob a influência de um novo mundo pictórico - as fotografias e ilustrações em perspectiva de seus livros. Sua antiga noção de "realismo" pictórico, que foi confiantemente baseada em sua intuição pessoal, foi subitamente destruída. O desenhista talentoso que você acreditava ser se tornara agora um fracasso vergonhoso. Talvez seus professores ainda tentassem lhe encorajar novamente, mas seus amigos... Com seus comentários avassaladores de desprezo... (“O que é isso?”). Você acha que era hora de encontrar outra coisa para merecer a aprovação de seus colegas. Consciente disso ou não, você estava sendo submetido a uma transformação psicológica tão completa que você nunca mais seria capaz de "ver" o seu mundo intuitivo, muito menos descrevê-lo.

A analogia acima tem, evidentemente, a desvantagem de confundir a evolução ascendente da arte renascentista ocidental com o crescimento biológico da criança, sugerindo que a arte chinesa ou árabe e, ao mesmo tempo, a habilidade do artista de "ver" permaneceram "infantis" enquanto o Ocidente "amadureceu”. De fato, alguns pensadores expressaram essa opinião, como o psicólogo suíço Jean Piaget (“A ontogenia recapitula a filogenia”). No entanto, não faz jus ao extraordinário e constante aperfeiçoamento das formas artísticas chinesas e árabes, que conseguiram uma expressão subjetiva bastante surpreendente, ainda que não fossem táo orientadas à "realidade objetiva" quanto as formas ocidentais. No século XIX, esses ideais imortais do Oriente retornariam, na forma de gravuras japonesas, forçando a pintura ocidental a fugir de sua obsessão pela "janela” e voltar à superfície decorada.

Segundo minha própria interpretação, no entanto, a arte infantil não é uma forma imperfeita de expressão adulta. É um sistema inteiramente distinto e independente de representação gráfica e que não é necessariamente melhorado pela perspectiva e nisso pode ser comparado à arte chinesa e árabe. $\mathrm{Da}$ mesma forma que a criança, o artista oriental adulto e refinado não enxergou volume nos espaços vazios que cercavam os objetos que ele pintava. O espaço pictórico era apenas o nivelamento neutro do papel. A relação dos objetos desenhados com o espaço entre eles era determinada por uma preocupação decorativa que levava em consideração a forma geral do papel. Assim como as crianças parecem "ver" seu próprio mundo imaginativo em função desse tipo de 
representação, é bem possível que adultos de civilizaçôes históricas anteriores ao advento da perspectiva linear não tenham "visto" a natureza da mesma forma como a vemos hoje. Millard Meiss mostrou como Santa Catarina de Siena, no século XIV, descreveu suas visóes milagrosas em termos obviamente extraídos dos clichês da pintura tradicional de sua época, desde o fundo dourado até as auréolas.

No artista ocidental dos anos 1300, entretanto, constatamos uma evoluçáo dessa atitude tradicional anterior à perspectiva. Considerando sua tela de pintura como uma "janela”, ele tinha que considerar o "espaço" não mais como uma superfície plana, mas como um volume que envolveria os objetos que ele retratava, por assim dizer, como um fluido transparente. Ele tinha que descrever o espaço vazio em torno desses objetos como se fosse outro objeto, sujeito à mesma estrutura geométrica. ${ }^{2}$

\section{A precedência da Antiguidade Clássica}

Não se trata aqui de julgar a qualidade da arte por ser ela baseada, ou não, no conceito de "janela". O que nos interessa é apenas descobrir porque o Ocidente adotou essa noção e qual foi o seu impacto na sua visão de mundo em relação ao Oriente. Uma das principais razóes que poderiam ter trazido esse conhecimento para o Ocidente - e que a partir de agora vamos examinar - é que já encontramos um precedente na antiguidade clássica. Até certo ponto, a arte chinesa e a islâmica também sofreram influência da Grécia e de Roma, mas foi obviamente o cristianismo ocidental que herdou mais diretamente a tradição clássica.

Examinemos uma ilustração de um afresco romano pintado na parede de uma sala em uma das villas preservadas de Pompeia (Figura 8). Notamos que o pintor da antiguidade decorou as superfícies das paredes com molduras imaginárias, contendo cenas claramente destinadas a não serem vistas na parede, mas fora dela e além. Temos aqui um precedente óbvio. Pode ser que eu insista muito nesse conceito de "janela", mas o fato é que ele pertence exclusivamente à civilização greco-romana. Nunca tinha aparecido antes, fosse no Egito ou em outro lugar. Os últimos pintores da antiguidade, quase conseguiram chegar à descoberta da perspectiva linear. Seja como for, o advento do cristianismo, ligado às idéias orientais, impediu todo progresso no caminho da perspectiva. Entretanto, no longo hiato entre a queda do Império Romano e o meio do século XIII, mesmo quando os artistas cristáos do Ocidente magnificamente exploravam as mesmas formas pictóricas que os chineses e os árabes, a arte ocidental manteve um vestígio da tradição greco-romana. Não há necessidade de recorrermos aos arquétipos de Jung.

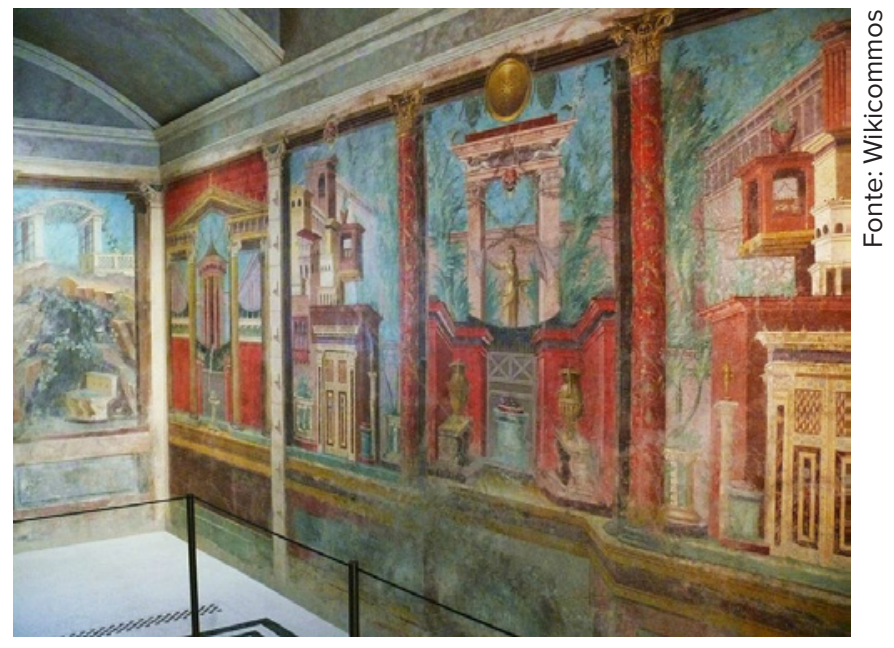

Figura 8: Detalhe do afresco mural do cubiculo na Villa de P. Fannius Synistor em Pompeia (Metropolitan Museum of Art, NY) 
Erwin Panofsky mostrou convincentemente como as convençôes greco-romana de proto perspectiva permaneceram por assim dizer "adormecidas" na arte medieval ocidental, como se estivessem esperando o "calor e umidade" do Renascimento para retornarem à vida!

\section{A óptica geométrica da Antiguidade}

Como o artista greco-romano considerou o quadro como uma "janela"? Nós encontramos a resposta na história da ciência e, mais uma vez, corresponde à descoberta de um fenômeno até então desconhecido na história da humanidade, ou seja, a ciência da óptica geométrica, que consiste em determinar como o olho humano vê de acordo com as regras euclidianas. Euclides, Ptolomeu e outros matemáticos gregos tinham determinado que a luz viaja sempre numa linha reta e pode, por conseguinte, traçar diagramas dos raios de luz sobre uma folha de papel. Além disso, esses raios convergem ao olho, na forma de um cone, ou seja, a maneira como as imagens são formadas e como elas aparecem deformadas por causa da posição ou da distância, podem ser determinadas precisamente aplicando-se as leis geométricas que, na matemática, governam cones, pirâmides e triângulos. Por outro lado, a ciência da óptica concomitantemente na China nunca se preocupou com uma explicação tão geométrica da visão; a geometria euclidiana só entrou na China no século XVII.

A Figura 9 mostra uma seção do olho humano, como antevisto pela óptica grega. Fisiologistas gregos, como Galeno, acrescentaram novos conhecimentos a essa ciência na época do Império Romano. De acordo com seu pressuposto fundamental, o cone de raios visuais não para exatamente na superfície do olho, mas, no seu interior, projeta uma imagem re- duzida numa membrana sensível, obedecendo as regras euclidianas, segundo as quais um triângulo tem exatamente as mesmas proporçóes de outro triângulo semelhante de dimensôes maiores. Galien pensou, como todos os especialistas em Óptica até o século $\mathrm{XVI}$, que esta membrana sensitiva sobre a qual se projetava a imagem reduzida dentro do olho era o que chamamos hoje de cristalino. Este, chamado no latim da época de cristallinus, foi descrito como um corpo transparente, semelhante a uma janela, que interceptava o cone visual antes que os raios convergissem, na ponta do cone, sobre o nervo óptico. Sabemos hoje que o cristalino é apenas uma membrana de convergência que direciona a luz para a retina, esta sim, o verdadeiro lugar da visão interior. No entanto, essa noção de interceptação pelo cristalino, mesmo errada, teria consequências importantes não

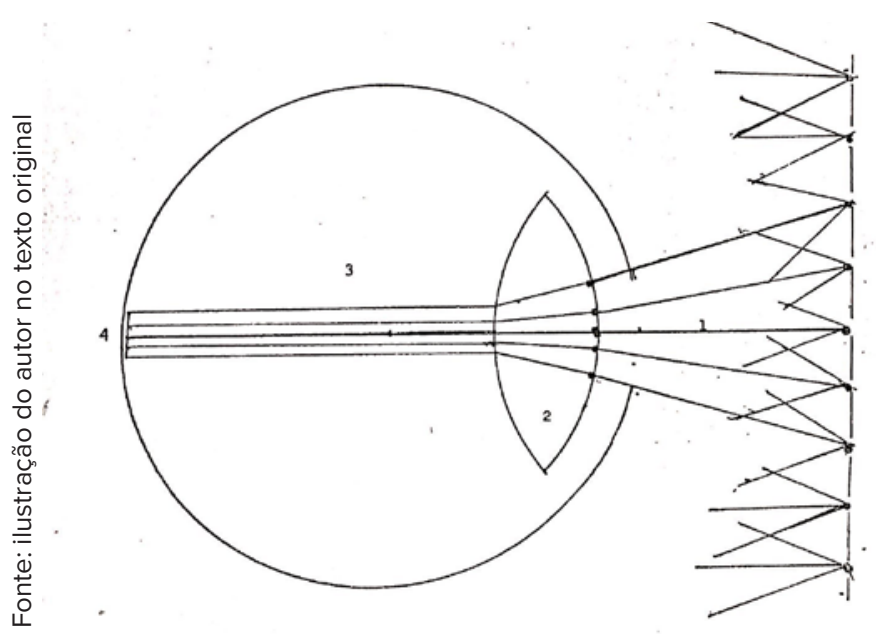

Figura 9: Diagrama do olho tal qual é apresentado na Óptica clássica, árabe e a ocidental da Idade Média. $O$ desenho mostra a concepção de Alhazen de como os raios visuais (1) penetram a pupila, impóem sua forma no cristalino (2), depois são refratados pelo líquido vítreo (3) de modo a transmitir ao nervo óptico (4) uma imagem corrigida. 
apenas para a concepção da pintura pelos pintores greco-romanos, mas para o reaparecimento da perspectiva linear na época da Renascença.

Não temos provas concretas de que os artistas clássicos realmente aplicaram esses conceitos ópticos à sua arte. No entanto, em Vitruvius e Lucretia encontramos algumas referências indiretas aos efeitos ópticos criados pelo menos pelos cenógrafos em seus cenários. Também sabemos que Ptolomeu, em suas obras de geografia, inventou um método de projeção cartográfica muito semelhante à perspectiva linear de Renascença. Retornaremos, mais tarde, à relevância dessa observação, mas podemos dizer de antemão que os artistas clássicos pareciam testemunhar em suas pinturas o que os cientistas da época descreveram como um elemento essencial no próprio processo visual em si, que o olho vê da mesma maneira que uma janela "recebe" a imagem da realidade em sua superfície, na interseção do cone visual.

Curiosamente, é o Islã que primeiro resgata a ciência óptica clássica do caos que levou à queda de Roma. Os estudiosos árabes, como Avicena e Hazin impulsionaram essa ciência muito além do que tinha ido Euclides, Galeno ou Ptolomeu. Diferente da antiguidade clássica, por outro lado, o mundo árabe não tinha tanto interesse em levar essa ciência ao conhecimento dos artistas. De fato, o iconoclasmo da religião muçulmana proscreveu das artes qualquer representação figurativa que pudesse "falsificar a obra de Deus". Com certeza, a iconoclastia não proibiu a arte figurativa em todos os lugares do Islá, como evidenciado pela arte persa, mas, em todo caso, excluiu a arte da panóplia didática da fé muçulmana. De um modo geral, a arte árabe permaneceu, assim, como a arte chinesa, um precioso instrumento do prazer estético do homem bem nascido. De fato, a atitude em relação às artes no Oriente era semelhante àquela que se manifestou no Ocidente apenas a partir do século XIX. A arte é para o espírito e não para a razão; ao contrário da política e da ciência, ela recorre à emoção subjetiva e não à inteligência objetiva. Essa certamente não foi a atitude de Giotto e seus contemporâneos do início do século XIV.

\section{A Renovaçáo das Ciências Ópticas a partir do Século XII}

Vejamos agora como a Ciência da óptica foi restaurada no Ocidente após o século XII. Retirando-se naquele momento da Espanha e da Sicília, os árabes deixaram um grande número de trabalhos científicos de Aristóteles, Euclides, Ptolomeu, Galeno e outros, acompanhados de comentários em árabe. Esses livros haviam despertado o interesse do mundo ocidental e um verdadeiro exército de escribas cristãos foi enviado para transcrevê-los em latim. Seus textos mais procurados eram sobre Óptica. Alguém pode se perguntar por que uma ciência tão matemática interessou o Ocidente cristão. Para tentar responder teremos de nos voltar para as obras de Roger Bacon, um monge franciscano do século XIII e, ele mesmo, autor de um Tratado de Óptica e uma obra polêmica e extremamente interessante sobre as obrigaçôes dos pintores.

Para bacon e outros estudiosos cristãos da Idade Média, a óptica geométrica exerceu um fascínio singular. Deus criou a luz no primeiro dia do Gênesis e a ciência da óptica explica como a luz se move de acordo com leis geométricas imutáveis. Parece, assim, que é a Óptica que pode fornecer o modelo que explica como Deus espalha sua graça divina no uni- 
verso. Aqui está uma passagem interessante do Opus Majus (1267), obra emblemática que reúne o conhecimento produzido por Bacon, que também contém um capítulo sobre Óptica:

"A infusão da graça, sendo claramente ilustrada pela difusão da luz, indica em todos os aspectos que através da difusão corporal da luz, as propriedades da graça manifestam-se para os bons e a rejeição da graça para os maus. Pois, para aqueles que são perfeitamente bons, a infusão da graça é comparada com a luz que brilha direta e perpendicularmente ... já que estes não rejeitam a graça refletindo-a e não a desviam, refratando-a, da linha reta que segue o caminho da perfeição na vida (...). Os pecadores, ao contrário, que estáo em um estado de pecado mortal, rejeitam a graça de Deus refletindo-a (...) “

Nenhuma outra religião, além do cristianismo, foi tão intoleravelmente dogmática na história do mundo, quer dizer, tão incisiva em suas tentativas de atrelar todos os aspectos da experiência e do conhecimento humanos à ditadura moral da Igreja. Os padres da Igreja sentiam-se obrigados a assimilar todo novo pensamento científico que se apresentasse. Cada aspecto do conhecimento deveria, pensavam eles, ser racionalizado em função da verdade revelada nas Escrituras e deveria ser encontrado seu lugar exato na interpretação moral da estrutura da "lei natural". É estritamente por esse ângulo, que a ciência da óptica voltou a florescer no Ocidente durante a Idade Média.

Os guardióes da ortodoxia na China e no mundo árabe, por outro lado, professavam uma tolerância tanto com a ciência, como da arte, porque não pareciam estar em conflito com a ordem fundamental do mundo. Exibiam, por assim dizer, para as artes e as ciências um "sorriso" - uma "negligência benevolente" que, em certa medida, as relegou a um posto sem importância, - um em sua pirâmide de poder absoluto. É, portanto, irônico que alguns historiadores modernos progressistas tenham interpretado passagens como as de Bacon como prova de uma supressão destinada a preservar a ignorância e a superstição. Eu diria antes que, se essa fosse a intenção da Igreja, seria bem-vinda, porque essa tática obviamente obtivera o resultado oposto. Uma "atenção maliciosa" pode, de fato, encorajar a criatividade melhor do que uma "negligência benevolente". De qualquer forma, a Igreja Ocidental examinou minuciosamente toda atividade artística ou científica para evitar a heresia e preservar a ortodoxia. A Igreja colocou à disposição de artistas estudiosos uma rede internacional de comunicaçôes e facilitou seu acesso ao ápice do poder, desde que eles pudessem comprovar que seu trabalho servia à causa da salvação por meio da fé cristã.

Também nesse sentido, vemos a exortação de Roger Bacon aos artistas, para não mencionar que ele a escreveu por volta de 1260 , assim como sua própria ordem franciscana preparava-se em Assis para acolher o grupo de pintores revolucionários que, talvez sob a direçâo de Giotto, irrevogavelmente guiaria a arte ocidental em direção ao Renascimento e à redescoberta da perspectiva linear. O próprio Bacon dificilmente poderia ser considerado um amante da arte. Ele só apreciava os artistas na medida em que eles assumiam sua responsabilidade didática em espalhar a mensagem da Igreja. Ele poderia não ter $\mathrm{o}$ entendimento de perspectiva, mas entendia, no entanto, claramente as implicaçóes morais de uma arte baseada nas leis da geometria. 
"Gostaria agora de apresentar a [proposta] relativa às formas geométricas relacionadas com as linhas, ângulos e figuras, tanto dos sólidos, quanto das superfícies. Pois é impossível penetrar no sentido espiritual sem conhecer o significado literal. Mas não podemos conhecer o significado literal sem conhecer os significados dos termos e das propriedades das coisas que eles designam. Pois é neles que está todo o escopo do significado literal, e é deles que extraímos a profundidade dos significados espirituais com a ajuda de adaptaçôes e comparaçóes apropriadas, da mesma forma que os escritores sagrados ensinam e como é evidente pela natureza das Escrituras, e foi assim que todos os sábios da Antiguidade interpretaram as Escrituras. Visto que, portanto, obras artificiais, como a arca de Noé, o templo de Salomão, Ezequiel e Esdras, e outras inumeráveis coisas dessa natureza, são mencionadas nas Escrituras, não é possível ao homem compreender seu significado literal sem que essas obras lhe sejam descritas em termos ao seu alcance, mas melhor ainda representadas em sua forma física; e assim os escritores sagrados e os sábios de outrora recorreram a imagens e a diversas figuras, a fim de fazer com que a verdade literal e, consequentemente, a verdade espiritual aparecessem aos olhos. Pois nas vestes de Aarão foram descritos o mundo e os grandes feitos dos pais. Eu vi Aarão, assim desenhado, com suas vestes. Mas ninguém poderia conceber e organizar a representação de assuntos desse tipo sem um bom conhecimento dos Elementos de Euclides (...) e os trabalhos de outros geômetras. Pois é a ignorância desses autores que leva os teólogos a se enganarem em assuntos da mais alta importância. (...) Oh, como a beleza inefável da sabedoria divina brilharia e o benefício infinito transbordaria, se esses assuntos e se os assuntos geométricos contidos nas
Escrituras, fossem colocados diante de nossos olhos em suas formas físicas! Pois assim, todo o mal do mundo seria destruído por um dilúvio de graça e nós seríamos elevados às alturas com Noé e seus filhos e todas as criaturas animadas coletadas em seus lugares e ordens. (...) Certamente a mera visão perceptível aos nossos sentidos seria bela, porém mais bela, já que veríamos em nossa presença a forma de nossa verdade, e mais bela de todas porque fora despertada pelos instrumentos visíveis e assim, deveríamos nos alegrar em contemplar o sentido espiritual e literal da Escritura, porque nosso conhecimento de que todas as coisas estão agora completas na igreja de Deus, que os próprios corpos sensíveis aos nossos olhos mostrariam. Portanto, não encontro nada mais adequado para um homem diligente no estudo da sabedoria de Deus do que a exibição de formas geométricas desse tipo diante de seus olhos. Oh, que o Senhor ordene que assim seja feito!

A concepção de arte que Bacon expôs aqui era muito distinta daquela da China ou do Islá. Ele imaginou uma arte não apenas inteiramente dedicada ao serviço da Igreja, mas, também, governada pelas mesmas leis matemáticas pelas quais Deus orquestrou o Universo. O público de Bacon no final do século XII era visivelmente diferente da sociedade feudal e hierárquica do início da Idade Média. Era a época na qual podemos, de fato, perceber os primeiros indícios do capitalismo moderno. Um período surpreendente em que, como disse Charles Trinkaus, "secularizou o sagrado e sacrificou o secular".

No entanto, não nos deixemos enganar. A expansão do capitalismo no Ocidente não levou, a princípio, a uma regressão do zelo religioso. Pelo contrário, nenhum esforço foi poupado para salvaguardar o bom 
entendimento entre Deus e Mamon. ${ }^{3}$ Como mostram os escritos de Bacon, a Igreja, que tinha muitos fiéis, não duvidava do seu poder de continuar a moralizar um mundo cada vez mais materialista. Sua melhor arma, de fato, era a ciência da matemática em si. Se a lei matemática é realmente o modelo através do qual Deus orquestra o universo, conclui-se que em qualquer manifestação das mesmas leis matemáticas no mundo secular estaria envolvida, em até certo ponto, a graça de Deus. O próprio capitalismo baseava seu sucesso na boa manutenção dos relatos e nos procedimentos matematicamente organizados, parecendo, assim, que ele também se encaixava na mesma harmonia divina.

Não é de se surpreender, portanto, que no século XIV, em particular, em todos os campos da atividade humana, tenha havido uma explosão de trabalho matemático, todos realizados com o entusiasmo da convicção de que Deus estendeu sua providência, assim na Terra como no Céu, para aqueles cujos assuntos foram mais matematicamente ordenados. A maioria dessas iniciativas começaram, o que é bastante interessante, na Itália, em torno da cidade de Florença. Foi nesse ponto que a contabilidade de dupla entrada $^{4}$ foi inventada, o que não apenas melhorou os métodos contábeis, mas também deu ao homem de negócios uma possibilidade que ele nunca havia conhecido de investir seu capital especulativo numa escala sem precedentes. Novos métodos foram desenvolvidos para traçar rotas marítimas comerciais no Mediterrâneo, que ofereciam menos riscos aos navegantes. O relógio mecânico foi inventado, permitindo o estabelecimento de um dia de trabalho regular, que não dependia mais dos caprichos do Sol a mudar de acordo com as estaçóes do ano. Novos sistemas de distribuição de terra foram adotados (a meação), no qual as plantaçóes eram distribuídas em terraços geometricamente dispostos, o que aumentava o rendimento. Poderíamos citar muitos outros exemplos. Naquela época, nem mesmo na China ou no mundo árabe, a matemática foi táo usada para resolver os problemas materiais do homem e ao mesmo tempo que abençoava suas realizações com o Céu. Como podemos observar no caso do comerciante florentino de Prato, Francesco di Marco Datini, que no fim do século XIV, fechava sua contabilidade todas as noites, escrevendo no topo da página: "Em nome de Deus e do lucro".

A partir do final do século XIII, a arte ocidental embarcou em uma direção muito diferente da arte chinesa ou árabe. $\mathrm{O}$ pintor, assim como seu mecenas e o público, não conceberam obra mais bela do que aquela que serviu à causa da Igreja militante. Também não era melhor do que um trabalho visivelmente geométrico em sua composição, que expressava através da imagem o apoio a uma sociedade religiosa, moral e fisicamente governada pela lei matemática. Eu particularmente quero enfatizar esse papel didático da arte ocidental. A arte passa a ser considerada cada vez mais como um instrumento de ensino e náo de contemplação poética. Essa crescente importância da pintura como ferramenta didática estava evidentemente destinada a ter impactos consideráveis para o Ocidente, em termos de Ciência.

\section{A redescoberta da perspectiva linear no Ocidente por volta de 1425}

\section{Brunelleschi}

Inevitavelmente é, no sentido dessa orientação, que a arte ocidental será inexoravelmente conduzida em 
direção à perspectiva linear. $\mathrm{O}$ desenvolvimento de regras precisas, derivadas da Óptica e do precedente histórico de Giotto e seus seguidores, não ocorreu até 1425 . Foi o escultor e arquiteto florentino Filippo Brunelleschi quem, primeiro, organizou essas idéias. Não entrarei aqui, em detalhes que já descrevi em The Renaisssance Rediscovery of Linear Perspective (New York, 1975). Vamos comparar novamente três quadros, provenientes, respectivamente, da China, do mundo árabe e do Ocidente e que datam de cerca de 1500 (Figura 10,11,12).

Pode-se observar imediata e inequivocamente que, nas duas primeiras figuras, as convençôes das artes chinesa e árabe para a representação de volumes no espaço não mudaram nem um pouco. $\mathrm{O}$ mesmo não pode ser dito sobre o trabalho ocidental que vamos

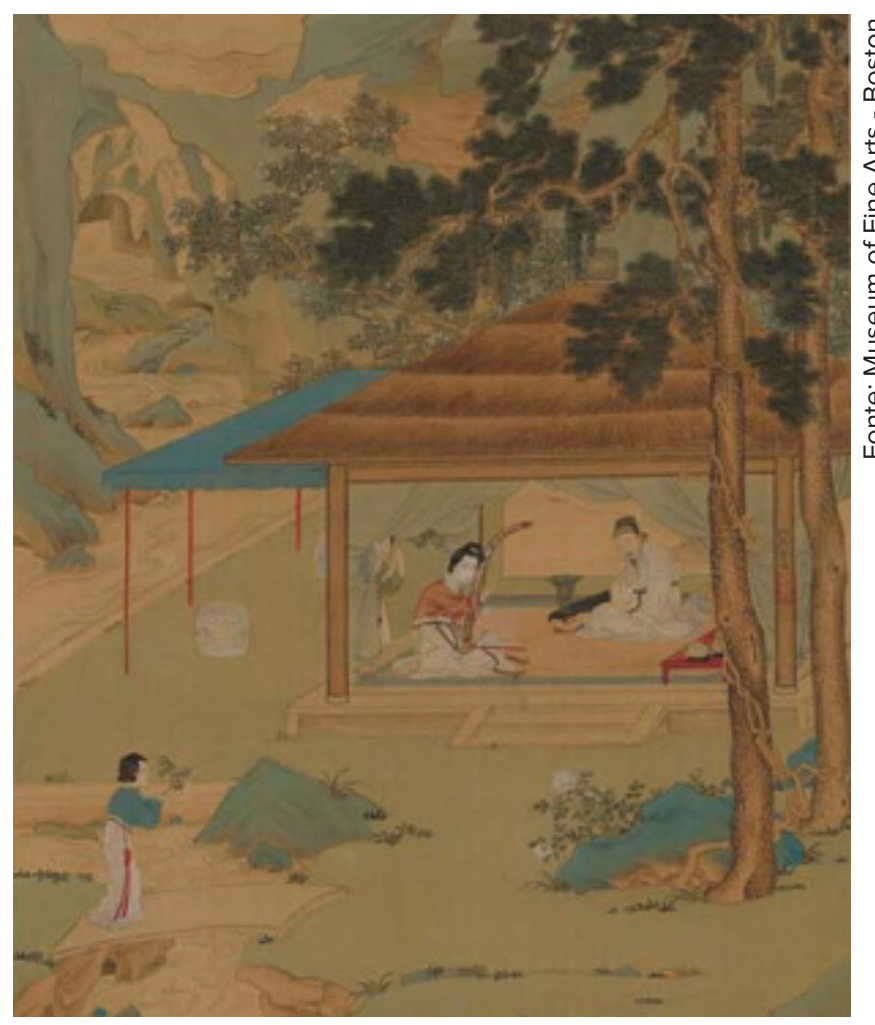

Figura 10: Pintura chinesa da Dinastia Ming, 1368 1644. Uma harpista tocando no pavilhão. discutir em detalhes, O Casamento da Virgem (Lo Sposalizio), do artista italiano Raphael, que data de 1504. Este é um excelente exemplo da descoberta fundamental de Brunelleschi: o mecanismo do "ponto de fuga" na perspectiva linear. Em 1425, Brunelleschi notou, talvez olhando através de um espelho, que o fenômeno que constatamos quando olhamos para uma sala ou para uma estrada que parece diminuir com a distância, é explicado pelo fato de que as linhas próximas e paralelas entre si, parecem se encontrar em um ou mais pontos que estão sempre no mesmo nível dos olhos de quem observa, é o que hoje chamamos de "linha do horizonte". Quando aparece em uma pintura, essa linha indica onde os elementos da pintura devem estar e onde o espectador deve posicionar seus olhos de modo a capturar

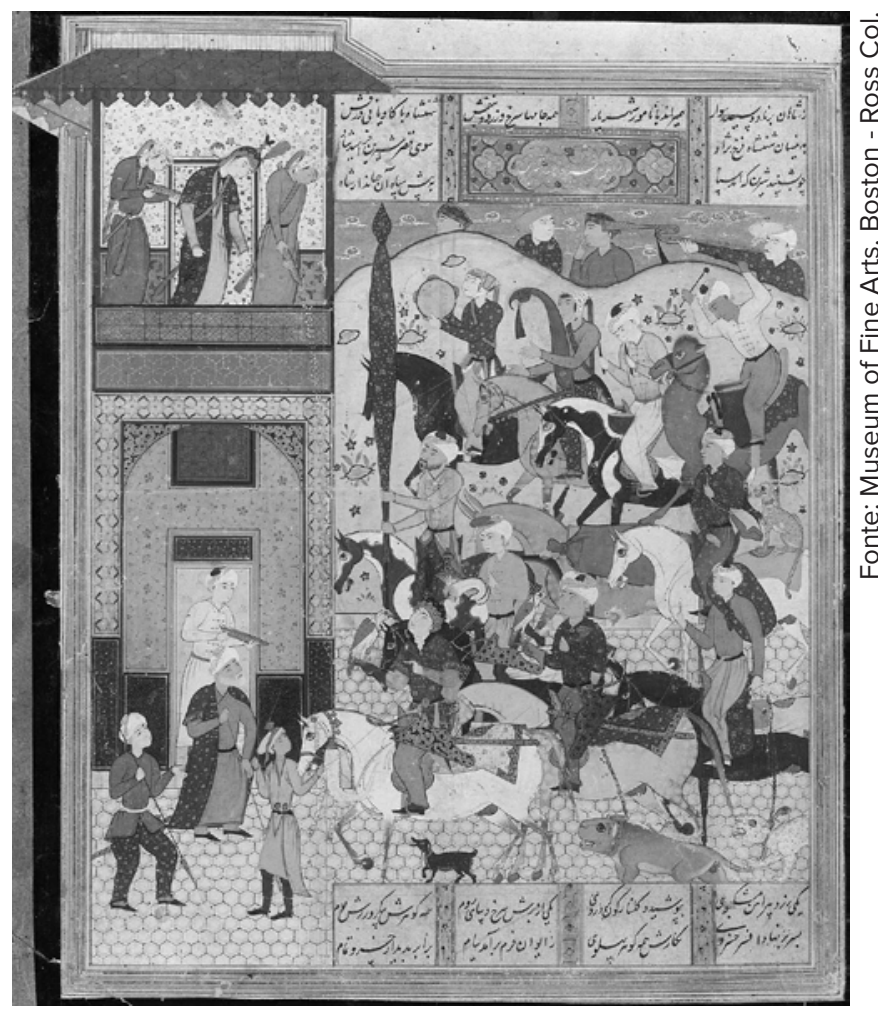

Figura 11: Pintura islâmica do séc. XVI, página do manuscrito do poeta Abul-Qasim Firdawsi

"Shahnama": Khusraw no portão do palácio de Shirin

Revista online do Departamento de Arquitetura e Urbanismo da Pontifícia Universidade Católica -

Puc-Rio - Rio de Janeiro Brasil

Ano 3 - N ${ }^{\circ} 5$ - ISSN 2446-7340 
exatamente a visão inicial do artista. O horizonte estabelece, assim, uma ligação óptica que, partindo do espaço real do espectador, "percorre" a superfície da pintura (exatamente como uma janela) e "penetra" no espaço da própria pintura. Além disso, Brunelleschi percebeu que, se o artista ou o espectador fica no meio de uma peça quadrangular (como acontece na pintura de Rafael), as linhas de fuga convergem para um único "ponto" no lado oposto da visão. É como se um raio imaginário passasse entre esse ponto e os olhos sendo perpendicular, ao mesmo tempo, à superfície dos olhos e ao quadro. Esse raio visual central (ver Figura 9), o único do cone visual que é perpendicular ao cristalino e à superfície do objeto observado, já era reconhecido há tempos, por estudiosos árabes e cristãos clássicos, como um elemento essencial para assegurar a transmissão mais clara e precisa da imagem visual para o cérebro. Todos os outros raios visuais penetram obliquamente no olho e transmitem a imagem com menos clareza. Como Roger Bacon observou, os raios oblíquos levam à refração e reflexão e podem ser comparados à maneira pela qual a graça é rejeitada pelos pecadores. $\mathrm{O}$ raio central, por outro lado, náo é refletido nem refratado, e por isso define matematicamente como a graça de Deus incide sobre os justos. Ao descobrir o mecanismo do "ponto de fuga", Brunelleschi permitiu ao artista retratar uma cena não apenas "realisticamente", mas também metaforicamente, na medida em que o "ponto de fuga" ocupa no quadro a posição mais clara e distintamente conectada ao cérebro do espectador. Assim, era lá que o elemento mais importante do quadro deveria ser colocado. Leonardo da Vinci, por exemplo, pintou a cabeça de Cristo logo acima do "ponto de fuga", na famosa obra em que retratou a última ceia e que se encontra em Milão.
No casamento da Virgem de Rafael, o "ponto de fuga" se encontra na porta aberta do edifício circular na parte de trás da pintura. Embora esta posição pareça desinteressante, teve um significado religioso para o espectador da Renascença. O edifício é na verdade o templo místico da Igreja, cuja porta aberta se encontra - com conotaçôes obviamente simbólicas - ligada ao olho do observador pelo raio central. A porta abre passagem através de todo o edifício, de modo que se vê o céu do outro lado. Raphael engenhosamente co-

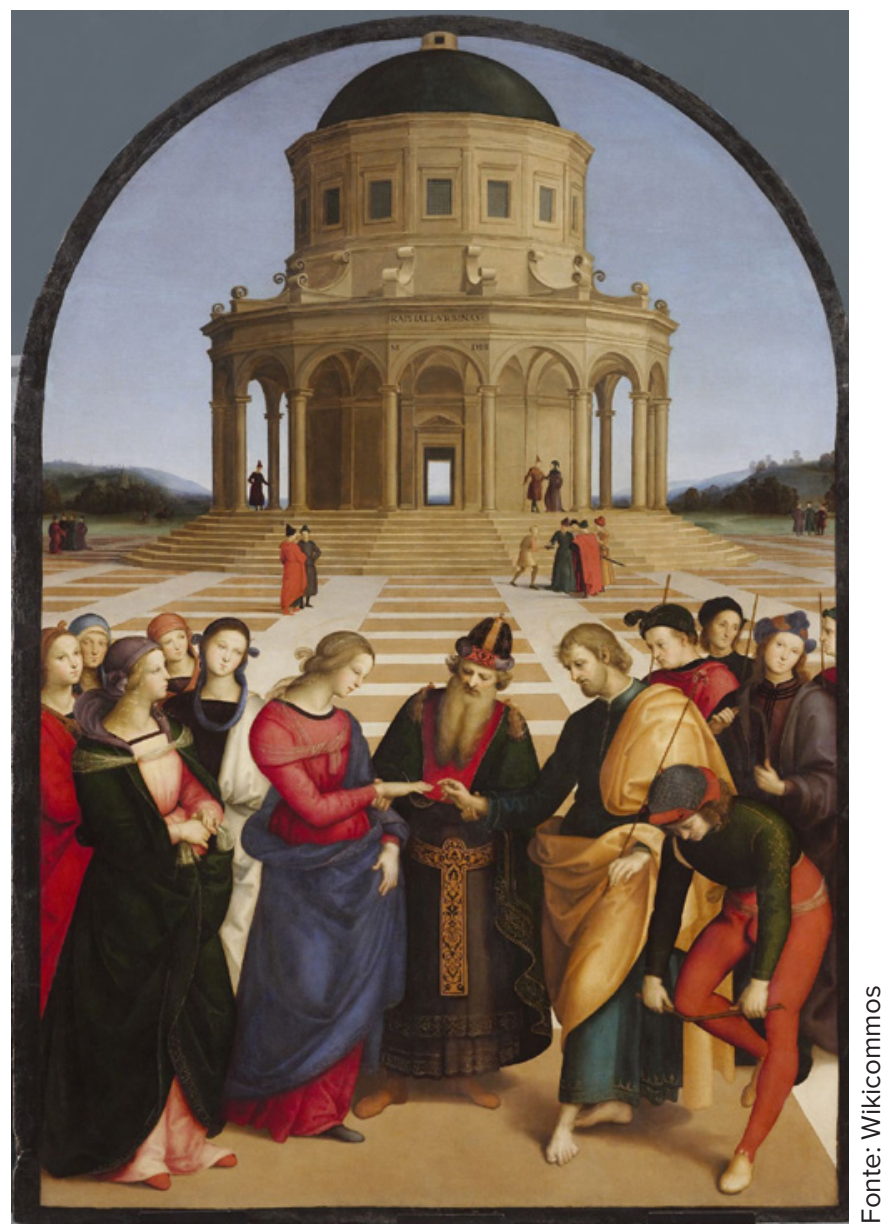

Figura 12: Pintura ocidental, 1504. Raphael, "O Casamento da Virgem”. (Milâo Galeria Brera) 
nectou a noção geométrica do "ponto de fuga" à idéia mística da infinidade de Deus no Céu, provavelmente a mais perfeita realização da orientação de Roger Bacon para fazer "literal" do "sentido espiritual". É interessante notar que um contemporâneo de Rafael, nascido como ele em Urbino, Luce Pacioli, escreveu, por volta da época do Casamento da Virgem, um certo número de tratados relevantes. Um deles lidava com contabilidade de dupla entrada, outro com os cinco sólidos regulares em geometria e outro, ainda estabelecia uma relação entre as artes figurativas (incluindo a tipografia) e as "proporçôes divinas" na matemática. Neste último tratado, ele escreveu que a perspectiva linear gerou uma arte superior à música, porque lisonjeava a visão, e superior à audição, uma vez que levava diretamente à inteligência.

No entanto, as convençôes pictóricas provavelmente mais importantes inventadas pelos pintores de perspectiva no Renascimento foram os "ladrilhos". No Casamento da Virgem de Raphael, vemos isso proeminentemente no chão que se estende por trás dos personagens principais. $\mathrm{O}$ fundo consiste aqui de linhas verticais e horizontais que convergem para o "ponto de fuga". Raphael usou o ladrilho no piso da grande praça que levava ao templo de modo que as linhas parecessem as bordas das placas de tamanhos iguais, mas que no primeiro plano são grandes e parecem diminuir conforme se distanciam. De fato, hoje, como comprova a psicologia moderna a malha de quadrados suscita uma espécie de estrutura inata e universal na mente humana. Quando desenhada com linhas convergentes que deveriam ser paralelas, dá a ilusão de uma superfície plana que, claramente, mergulha na distância.

\section{Perspectiva linear e cartografia}

Artistas ocidentais haviam observado esse poder singular ao se ladrilhar o piso, bem antes de Brunelleschi. Era quase um clichê entre os pintores italianos e franceses da protoperspectiva no século XIV, enquanto a arte chinesa ou árabe raramente a usava. $\mathrm{O}$ que é particularmente interessante, no entanto, na nova aplicação de tal ladrilhamento na perspectiva no século XV é que ele se tornou moda exatamente no mesmo tempo e lugar que outra ideia muito semelhante na ciência da cartografia: a redescoberta do sistema de longitudes e latitudes usado para desenhar a superfície da Terra que Ptolomeu havia descrito em seu Cosmografia - tratado do último período clássico que curiosamente escapou à atenção do Mundo Ocidental no século XII. Esse tratado só apareceu pela primeira vez na Europa Ocidental em 1400, em Florença, onde muito provavelmente o próprio Brunelleschi o tenha visto.

Ptolomeu descreveu métodos para resolver o eterno problema dos cartógrafos: como desenhar o mapa de uma superfície curva em uma folha de papel plana. Ele, assim, dividiu a Terra, que ele já enxergava como uma esfera, com a ajuda de um conjunto de linhas abstratas: meridianos verticais convergindo para os polos, cortados por paralelos horizontais. Ptolomeu sendo estudioso da Óptica, bem como geógrafo, orientava o observador a ficar na frente do modelo fixando seu raio visual frontal um pouco acima do Equador, que na antiguidade era considerados o centro do mundo (Figura 13). Os quadrados desenhados sobre a superfície da Terra, mais próximas do ponto em que o olho as via diretamente, pareciam regulares, enquanto aqueles nas partes da Terra que se

Revista online do Departamento de Arquitetura e Urbanismo da Pontifícia Universidade Católica -

Puc-Rio - Rio de Janeiro Brasil

Ano 3 - Nº5 - ISSN 2446-7340 
curvavam em direção ao polo pareciam se encolher. A partir desse fenômeno da perspectiva, Ptolomeu tentou desenvolver uma técnica de mapeamento que deixava ao espectador a tarefa de "corrigir" as distorçôes dessas latitudes norte ou, em outras palavras, tirar partido da ilusão psicológica da perspectiva da malha quadriculada (Figura 14).

Mais uma vez, esse súbito aparecimento no Ocidente de um sistema cartográfico baseado na divisão abstrata da superfície da Terra em quadrados geométricos já era muito conhecido no Oriente. O Islá, de fato, conseguiu preservar a Cosmografia de Ptolomeu entre os seus outros tesouros clássicos do conhecimento

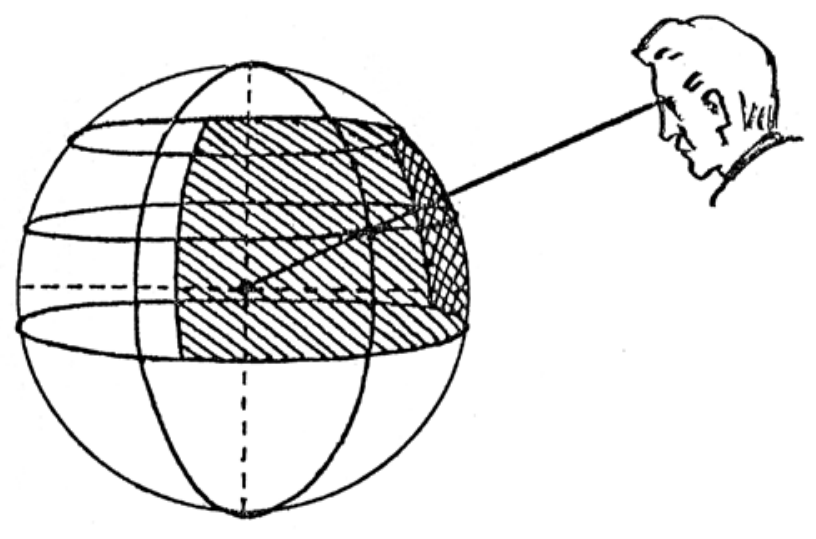

Figura 13: Diagrama que mostra a maneira defendida por Ptolomeu para estabelecer o eixo visual, definindo um ponto do globo no centro da área a ser reproduzida no mapa (o oikumene) ligeiramente acima do equador.

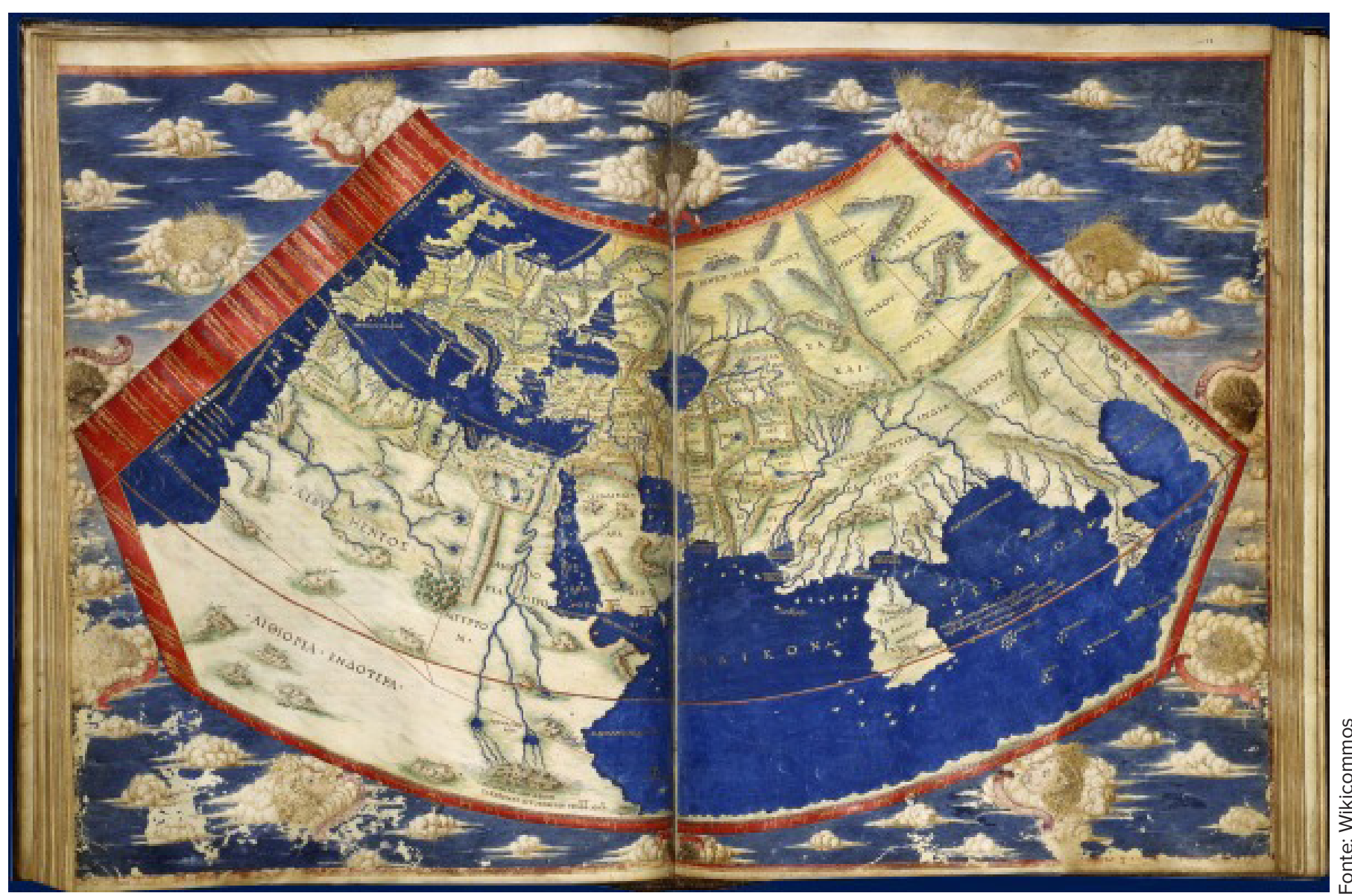

Figura 14: O mapa do mundo (ou oikumene) de Ptolomeu, a partir de um manuscrito grego que chegou em Florença por volta de 1400 (Biblioteca Medicea Laurenziana, Florença) 
e, como no caso da óptica, enriquecido com muitos comentários. A China, sem saber diretamente de Ptolomeu, desenvolvera, no entanto, um sistema de representação cartográfica baseado nos mesmos aspectos da psicologia visual da grade de quadrados. Nenhuma das duas civilizaçóes, no entanto, jamais estabeleceu uma relação entre essa técnica cartográfica e a arte.

\section{Toscanelli}

No Ocidente, por outro lado, a relação entre arte e cartografia ptolomaica começou a se manifestar quase imediatamente após seu aparecimento em Florença. Um dos amigos pessoais de Brunelleschi foi Paolo dal Pozzo Toscanelli, que estava profundamente interessado no estudo e disseminação das teorias cartográficas de Ptolomeu. A sobreposição dos círculos pessoais de cada um atesta essa amizade e também o interesse de ambos na ciência da matemática. Inúmeros indícios levam a crer que Brunelleschi, que não possuía formação acadêmica, consultou Toscanelli sobre questóes de Óptica, ao desenvolver seus primeiros experimentos em perspectiva linear. Há também uma forte razão para se acreditar que Toscanelli, médico diplomado em universidade, que também tinha um sólido conhecimento de geometria, Óptica, Astronomia e Geografia, tenha mostrado a Brunelleschi os sistemas de projeção cartográfica de Ptolomeu, incutindo-lhe, assim, a "ideia fixa" de resolver definitivamente a questão de como traçar a malha quadriculada para dar a ilusão da perspectiva linear.

\section{Alberti}

Dez anos depois de Brunelleschi finalmente ter "redescoberto" a perspectiva linear, outro humanista florentino, amigo ainda mais íntimo de Toscanelli, chamado Leon Battista Alberti, escreveu um famoso livro sobre pintura, chamado Della Pittura (14351436), no qual ele explica pela primeira vez ao mundo como produzir um quadro em perspectiva. $\mathrm{O}$ sistema de Alberti é obviamente baseado no trabalho de Brunelleschi, a quem ele presta homenagem. Ele também mostrou, em detalhes, como desenhar a "grade de quadrados" da perspectiva na forma do que ele chamou de pavimento. Alberti também orientou o artista sobre como fazê-lo. Ele deveria olhar primeiramente para a cena que ele ia pintar. Essas orientaçốes são de suma importância para a tese que estamos apresentando. O artista deveria usar um "véu" muito fino, de tecido pouco fechado, tinto com a cor que se quiser, com fios mais grossos formando

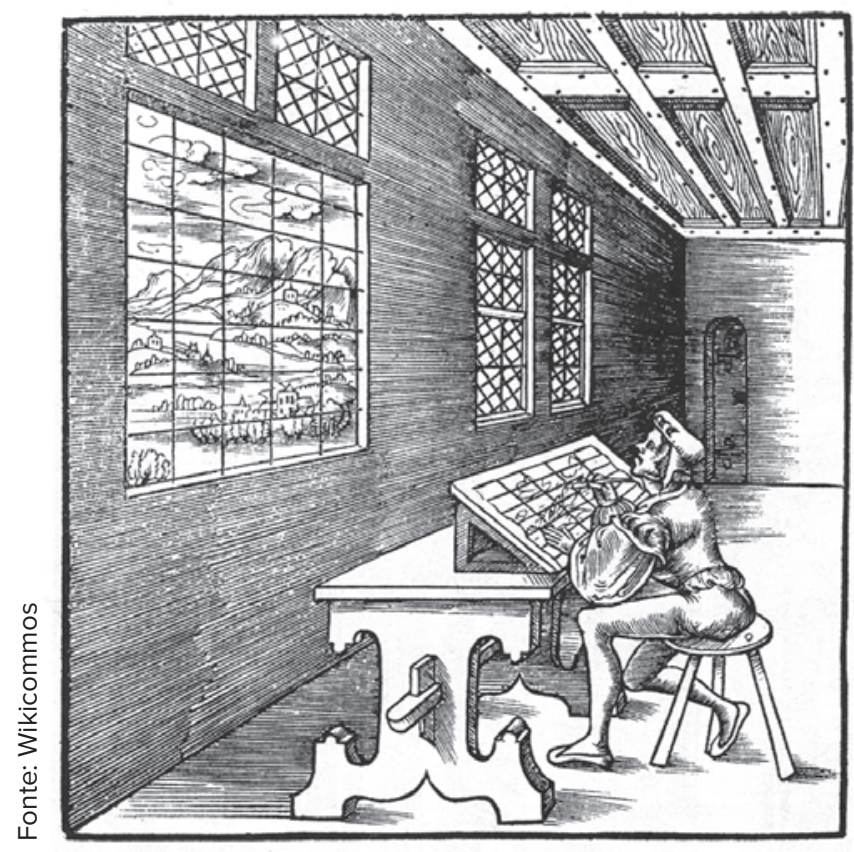

Figura 15: Um artista usando o "véu" de Alberti. Johann da Baviera e Hieronymous Rodler, Ein schön nützlich Büchclein und Unterweisung der Knust des Messens (Simmern, Alemanha, 1531) 
quantas paralelas se queiram e dispor esse véu entre o olho e a coisa vista, de modo que, para que a pirâmide visual penetre pela tela do véu (...) (Figura 15). Este método tinha, segundo ele, a vantagem "de que a posição dos contornos e os limites das superfícies poderiam ser facilmente posicionados exatamente no painel pintado, pois assim, num paralelo se verá a fronte, naquele o nariz, no outro as bochechas, no de baixo o queixo (...). Pode-se localizar precisamente todas as características do painel(...) que você dividiu da mesma maneira (...) você pode ver qualquer objeto redondo ou saliente representado na superfície plana do véu."

O texto de Alberti quase parafraseia as instruçóes análogas de Ptolomeu quanto à elaboração de mapas. Alberti não era apenas um amigo de Toscanelli, mas, ele também, desenhava mapas ptolomaicos, incluindo um de Roma mostrando a localização dos monumentos clássicos.

As obras de Alberti, no entanto, vão além da técnica simples de desenhar. Seu tratado sobre pintura foi, de fato, um manifesto para uma nova maneira de ver o mundo, bem como, deretratá-lo. O leitor (mais frequentemente um patrono do que um pintor) foi instado a olhar a natureza não mais como uma massa heterogênea de detalhes dispersos, mas como uma abstração homogênea matematicamente organizada. $\mathrm{O}$ todo tinha que ser apreendido antes das partes. Atualmente, quando usamos "colocar as coisas em perspectiva", expressamos exatamente o que Alberti quis dizer enfatizando a importância da perspectiva linear, ou seja, que náo era apenas uma questão de pintar um quadro que parecesse "real", mas sim, criar uma metáfora para ilustrar o pensamento racio- nal. Alberti estava muito preocupado que o tema da pintura fosse sempre digno da mensagem didática e enobrecedora que convinha ser transmitida ao espectador. Ele também estava convencido de que, se tais assuntos fossem retratados de acordo com as regras matemáticas da perspectiva linear, o espectador seria encorajado a "ver" também do ponto de vista da razão. A atitude de Alberti em relação à "visão" corresponde, portanto, ao que esperamos hoje daqueles que estudam ciência.

Não é possível provar que os chineses ou os árabes do século XV foram ineficientes em comparaçáo aos ocidentais, no que concerne ao entendimento da "visão". No entanto, nada pode ser comparado a obsessão que, no início do renascimento, assolava o Ocidente em todas as áreas da atividade humano. Não só artistas e cartógrafos eram adeptos fanáticos do "conceito de quadriculamento", mas também arquitetos, urbanistas, engenheiros militares, comerciantes, políticos e até sacerdotes de púlpito. Onde quer que se olhasse na Itália no século XV, havia alguma aplicação da organização geométrica. Se a cultura ocidental do início do Renascimento pudesse ser descrita em uma palavra, essa palavra seria: retilínea.

É lamentável que Paolo dal Pozzo Toscanelli não seja mais conhecido. Como humanista e acadêmico, era certamente mais próximo de Alberti, do que do artesão de uma classe mais modesta que era Brunelleschi. Quão fascinantes e profundas devem ter sido as conversas entre Alberti e Toscanelli sobre os assuntos que seriam de interesse de ambos, em matemática e cartografia! Pode-se imaginar esses dois estudiosos, em suas togas, discutindo arte, examinando a maneira como a perspectiva linear aplica-se em um quadro 
e a forma que o pavimento ladrilhado pode ser usado para medir a superfície, tanto em um mapa quanto em uma pintura (...) A Figura 16 reproduz uma pintura italiana de cerca de 1475, de um tipo cada vez mais comum desde o tratado de Alberti. Ela pertence naturalmente à mesma tradiçáo que o casamento da Virgem de Rafael. O tema é a Anunciação, e Toscanelli certamente havia visto exemplos semelhantes quando escreveu, na mesma época, uma carta memorável, talvez uma das mais decisivas da História, para Fernão Martins, próximo do rei de Portugal:

"Para Fernão Martins, cônego de Lisboa, de Paolo, o médico. Saudaçôes(...) Eu já tive a oportunidade de falar com você sobre uma rota marítima mais curta para as terras de especiarias do que aquela que vocês usam para a Guiné. Agora [seu] Sereno Rei me pede uma apresentação ou, de preferência, um esboço, que possibilite com que os traçados dessa rota sejam compreendidos por homens de pouca instrução. Embora eu saiba que é possível fazê-lo na forma de uma esfera comparável à Terra, decidi, entretanto, por mais clareza e simplicidade, representar [esse caminho] à maneira das cartas náuticas. Portanto, envio a Sua Majestade um mapa feito por minhas próprias mãos, que mostra todas as ilhas, diante das quais a oeste é pintado o início da Índias, com as ilhas e os lugares onde você deve navegar para poente, assim como as terras, onde você deveria fazer escalas e até que ponto se distanciar do polo ou do equador e depois de qual distância, isso é, no final de quantas léguas, você deve atingir a terra, mais rica em especiarias e pedras preciosas de todas as espécies e não se surpreenda que eu chamo as regiôes onde estão as especiarias de "ocidentais", porque aqueles que navegam para oeste sempre irão, sem dúvida, encontrar essas regiôes no Ociden- te (...). As linhas retas desenhadas verticalmente no mapa indicam, portanto, a distância de leste a oeste e aquelas traçadas horizontalmente indicam os espaços de sul a norte (...) Desde a cidade de Lisboa, em linha reta a oeste até à nobre e esplêndida cidade de Quinsai (China), são mostrados no mapa 26 espaços cada um dos quais com 250 milhas (...) O espaço a cobrir em águas desconhecidas, portanto, não é muito grande. Sem dúvida, seria necessário expor outros detalhes mais claramente, mas o leitor atento deve ser capaz de deduzi-los a partir deste esboço. Adeus, querido amigo."

A carta é datada de 1474, dezoito anos antes da viagem de Cristóvão Colombo. O mapa de Toscanelli infelizmente não existe mais, mas foi transmitido da mesma forma que a carta ao marinheiro genovês. Cristóvão Colombo também se correspondia com o velho médico florentino e muitos historiadores acreditam que foi especialmente o apoio de Toscanelli que permitiu que Colombo permanecesse fiel à sua visão, até que os espanhóis lhe dessem condiçôes de realizá-la em 1492.

Por que a América foi descoberta pelo Ocidente? A técnica naval dos chineses e árabes era tão boa quanto a do Ocidente, como evidenciado pela expansão marítima desses dois poderes no Oceano Índico durante o século XV. Então, por que não houve um Colombo chinês ou árabe?

Poderíamos arriscar respondendo: porque não houve um Toscanelli chinês ou árabe. E não poderia realmente existir, porque, como vimos, o tipo de diálogo entre artistas e estudiosos, que se tornou endêmico no Ocidente depois do século XIII, era completamente ausente na China e no Mundo Árabe. Não 


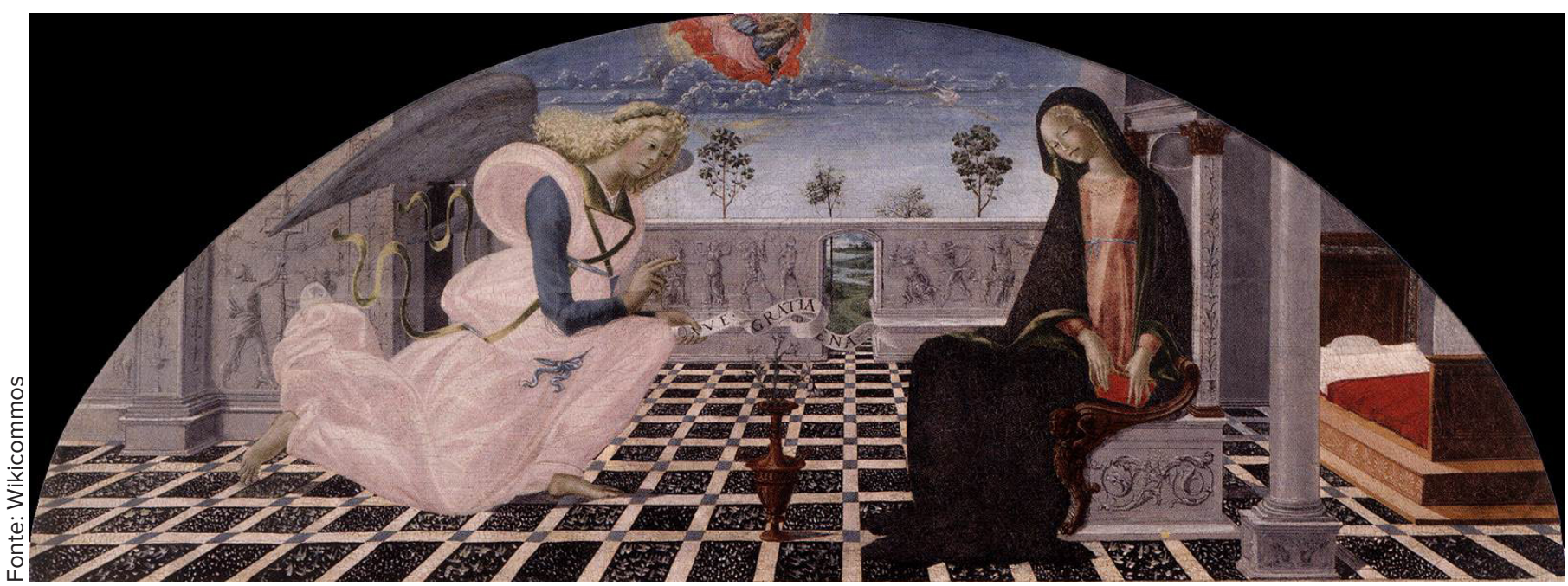

Figura 16: Pintura ocidental, cerca de 1475. Neroccio di Landi, "Anunciação".

(Yale University Art Gallery, New Haven, Conn.)

tendo nenhuma tradição da pintura como um instrumento didático, essas duas civilizaçôes não estabeleceram uma relação entre a arte e aquelas "leis naturais" de Deus que matematicamente estabelecem a organização do universo. No entanto, até que ponto poderíamos ousar considerar a hipótese de relaçóes entre um estudioso como Toscanelli e as artes visuais? Que elemento particular da Renascença, além da óbvia relação estabelecida pelo "mosaico" entre cartografia e perspectiva, poderia ter lhe dado uma ideia tâo ousada quanto a de uma rota para o oriente indo em direção ao ocidente?

A resposta a essas perguntas pode ser, em certa medida, a maneira pela qual um espectador da Renascença deveria olhar para a imagem da Anunciaçáo (Figura 16). A Itália do século $X V$ permaneceu, como vimos, tão preocupada com sua salvação espiritual quanto com o comércio de especiarias. Enquanto homens de ciência como Toscanelli ensinavam aos quatro cantos da Terra o respeito pelas leis da natureza, os teólogos estavam ansiosos para fazer com que esse novo conhecimento se encaixasse no dogma religioso. Quanto aos artistas, eles tiveram que seguir o progresso da ciência, bem como de sua interpretação teológica. Uma evolução interessante ocorreu, assim, em meados do século XVI na maneira em que o milagre da Anunciação deveria ser incluído. O tema e a composição tiveram que se adaptar não apenas à perspectiva linear, mas também a um novo e mais austero significado da encarnação divina. $\mathrm{O}$ espectador não fixa sua atenção em uma sala íntima onde se encontram o anjo Gabriel e a Virgem Maria, mas sob o raio visual central. Ele olha entre eles e fixa seu olhar em uma porta aberta. Antes de tudo, devemos notar que a luz que ilumina a cena é uniforme e vem da esquerda da pintura, tal qual o anjo que entra por esse lado, assim como a pomba carregando a semente divina. O lado esquerdo, portanto, representa a direção mística, les- 
te, onde o sol nasce, que traz a verdadeira luz para os homens deste mundo, "a fonte de toda a ressurreição e reencarnação. Buscando a unidade geográfica e óptica, o artista estabeleceu, portanto, que a porta dos fundos deveria se abrir para a direção igualmente mística do "sul" (além da porta, a paisagem é quente e alegre). É um exemplo perfeito do fato de que o Renascimento poderia combinar ciência e religiáo em um quadro perfeitamente didático. $\mathrm{O}$ pecador deveria se imaginar no gelado norte do seu próprio pecado. Cheio de esperanças, ele olha "através" do quadro janela, tendo fé que contemplando o mistério da encarnação de Deus vindo do leste, ele poderia compreender o maior de todos os mistérios - a bondade de Deus, que é simbolizada perfeitamente pelo calor que vem do sul. $\mathrm{O}$ chão quadriculado, bem em evidência nessa nova versão da Anunciação, é mais do que uma grande proeza. É um mapa ptolomaico traçando o caminho do olhar do espectador, desde os pecados do mundo até a salvação celestial.

\section{Perspectiva linear e organizaçáo do espaço visual}

Hoje somos as crianças mimadas da Renascença. Estamos muito acostumados com a perspectiva linear. Em vez de sermos seduzidos pela sua novidade, assim como os europeus do século XV, tendemos a pensar que artistas da Renascença, como o pintor da Anunciação, venderam sua criatividade por um prato de "realismo" e lentilhas matemáticas. No entanto, se pudéssemos nos reportar, pelo menos em pensamento, ao tempo de Toscanelli, deveríamos abandonar nossos preconceitos modernos e entender o quanto esse novo sistema de perspectiva pôde induzir os homens a uma reflexão mais aprofundada do que jamais houvera antes sobre a natureza dos homens e de Deus. Em particular, a perspectiva linear nas pinturas parece ter encorajado o espectador da Renascença a pensar na distância - ou melhor, na distância organizada - em que a matemática permitia "ver", como nunca havia feito antes, e conceber o espaço não como entidade finita e heterogênea, mas como um conjunto uniforme infinito e homogêneo. Acredito que a satisfação experimentada no início do Renascimento diante das pinturas em perspectiva não tenha sido muito diferente daquela experimentada por uma pessoa que sempre andou a pé ao voar pela primeira vez. Os obstáculos locais e desvios, que atrapalham o pedestre, de repente desaparecem e perdem toda a importância quando vistos de cima. A impressão produzida pelas pinturas em perspectiva e pelos mapas ptolomaicos deve ter sido comparável a isso. Podemos considerar que Cristóvão Colombo foi sensível a essas pinturas? O medo medieval tradicional do oceano misterioso, por exemplo, que por tanto tempo mantinha os homens em terreno firme, deve ter recuado pelo menos parcialmente diante do poder da malha de quadrados. Podemos facilmente imaginar Colombo explicando aos céticos que deveriam "ver" o grande oceano não como uma série de obstáculos assustadores, inexplicáveis e incomensuráveis, mas como Toscanelli o descreveu, ou seja, uma simples extensão de quadrados ptolomaicos, absolutamente racionalizados e sujeitos ao espírito do homem, bem como à sua vontade. Mark Twain relatou uma experiência semelhante. Em seu livro, Vida no Mississipi (1883), ele conta como, na infância, era encantado com o espetáculo deste rio poderoso, pela variedade de cores e beleza estética do seu curso sinuoso. Entáo, quando adulto, tornou-se piloto de um barco fluvial, a indiferença alegre com que

Revista online do Departamento de Arquitetura e Urbanismo da Pontifícia Universidade Católica -

Puc-Rio - Rio de Janeiro Brasil

Ano 3 - Nº5 - ISSN 2446-7340 
havia se entregado aos inesperados encantos vistos do velho rio, deu lugar a uma concepção nova e intelectualizada. Ele, então, teve que aprender a "re-ver" o rio como uma forma simples, fria e pouco inspiradora, de comunicação. Vou abrir um parêntese para lembrar, a propósito, que Cristóvão Colombo nasceu quase que na mesma época que Leonardo da Vinci e a apenas duzentos quilômetros de distância.

\section{Perspectiva e a representaçáo científica do real}

\section{Leonardo Da Vinci}

Pelas razóes já mencionadas, tampouco havia um Leonardo da Vinci naquela época na China ou no Islá. Grandes artistas e grandes eruditos abundavam no Oriente, mas nenhum deles era as duas coisas ao mesmo tempo. $\mathrm{O}$ gênio de Leonardo ainda intriga os ocidentais, que o consideram um tipo de mutação da espécie ou um fenômeno psicótico. Talvez fosse melhor, no entanto, ver nele um espírito muito brilhante e ávido, nascido na hora e local certos. A sorte de Leonardo não residia apenas no seu QI elevado, mas principalmente no fato de ter nascido perto de Florença na mesma época em que as ideias de Alberti e Toscanelli passavam a ser adotadas pelos artistas. É necessário, no entanto, agradecer ao Criador por tê-lo dotado de talentos científicos e artísticos incomparáveis a qualquer outro contemporâneo seu. Embora ele seja mais conhecido por sua pintura, Leonardo se considerava principalmente um erudito. Ele sempre quis ser um grande engenheiro e inventor, responsável pela execução de grandes obras de fortificações, armamentos, hidráulica, entre outros, para prestigiosos mecenas. Foi apenas por acaso que ele se tornou um pintor. Estudiosos modernos podem se regozijar por ele ter consagrado grande parte de sua arte à Ciência, enquanto os historiadores da Arte podem lhe agradecer por ele ter aplicado tão pouco de suas ideias científicas (às vezes um pouco exageradas) à sua pintura maravilhosa. Difícil de entender...!

Para Leonardo também, a perspectiva linear não era uma simples convenção pictórica. Ela fazia parte integrante de sua concepção da natureza. Ao "ver" em perspectiva, Leonardo poderia, melhor do que qualquer outro estudioso de novas técnicas anteriores a ele, conhecer os esquemas e estruturas nos quais os fenômenos físicos e biológicos são baseados (Figura

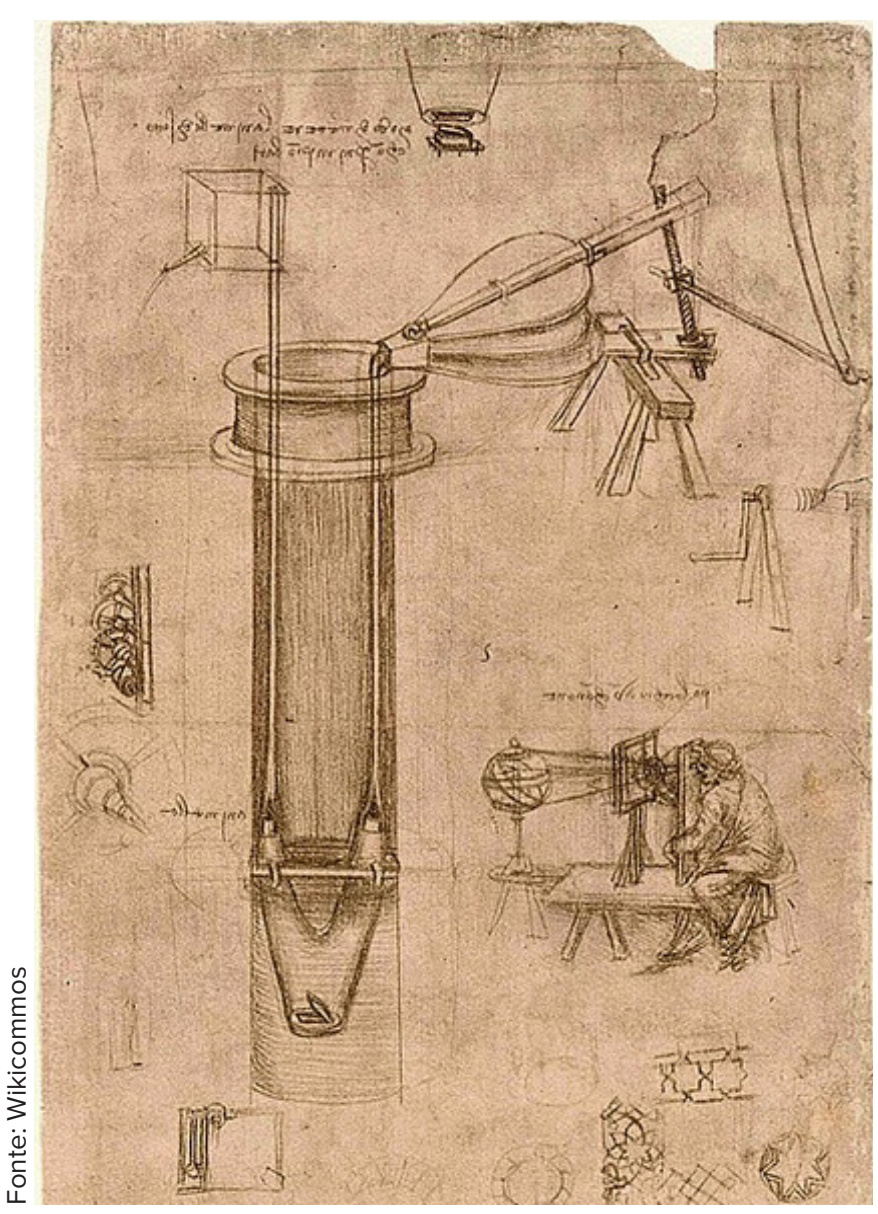

Figura 17: Leonardo da Vinci, página do Codex Atlanticus.(Biblioteca Ambrosiana, Milāo) 
17). Ele parecia estar ciente desse poder particular de perspectiva quando escreveu: "O olho é o mestre da Astronomia. É ele quem cria a Cosmografia. Ele guia e corrige todas as artes humanas(...). Transporta os homens para outras partes do mundo. Ele é o príncipe das matemáticas (...). Ele criou a Arquitetura, a perspectiva e a pintura sagrada (...) Ele descobriu a navegação.”

\section{Vesálio}

Até agora apenas examinamos a notável relação existente entre a perspectiva e as ciências matemáticas e físicas. Ela teve impactos, igualmente profundos, para as ciências biológicas e particularmente impor-
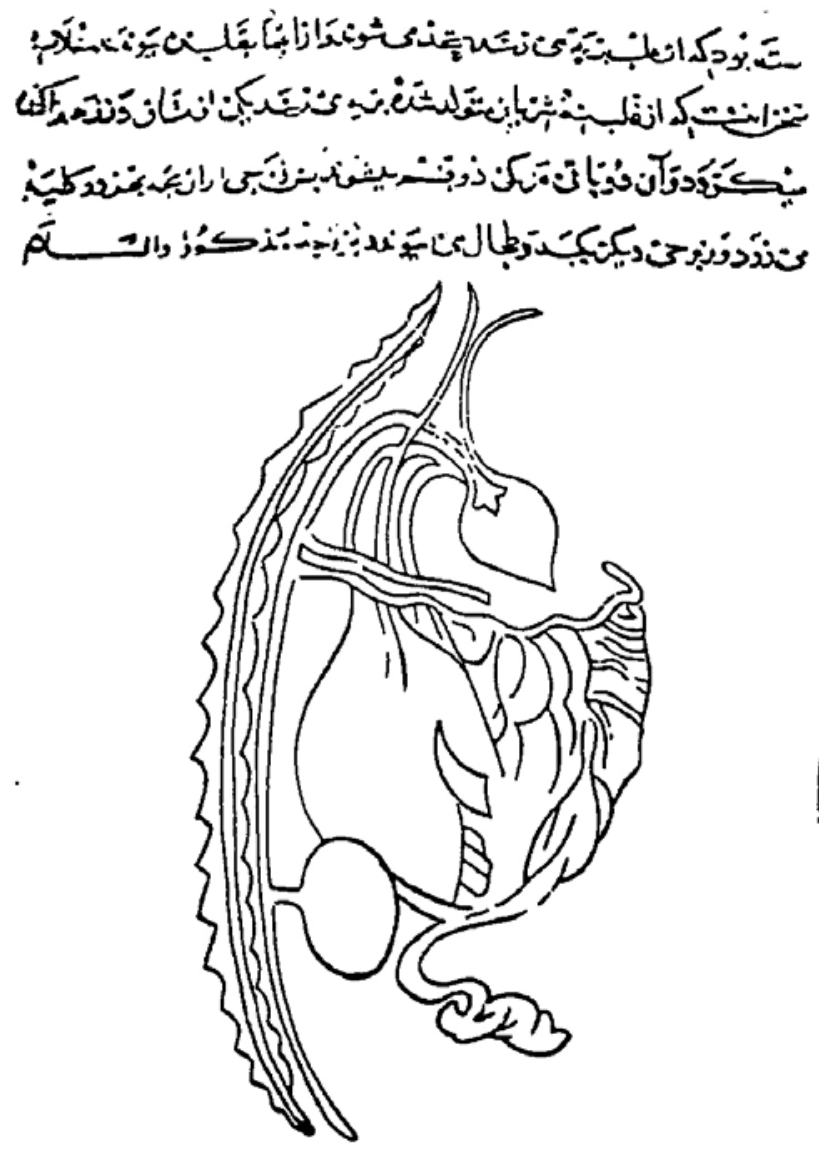

Figura 18: Visceras humanas por Rashid al-Din,

Tanksug-namah Ilkhan dar funun-i Khitai (Os tesouros de Ilkhan sobre as ciências do Catai), Pérsia, 1313. tantes para a anatomia. Tomemos agora nossa última série de três representaçôes gráficas, extraídas desta vez, de um texto italiano sobre a anatomia do final do século XIV, o outro de um tratado árabe do século XVI sobre o mesmo assunto e o terceiro da obra de André Vesálio, intitulada Fabrique du Corps Humaine, publicada na Basileia em 1543 (Figuras 18, 19, 20).

As duas primeiras imagens (e poderíamos facilmente ter tomado um exemplo chinês) apresentam, como de costume, os órgáos e músculos do corpo humano sob a forma de desenhos planos e lineares. Eles não dão nenhuma noção de profundidade e de modo

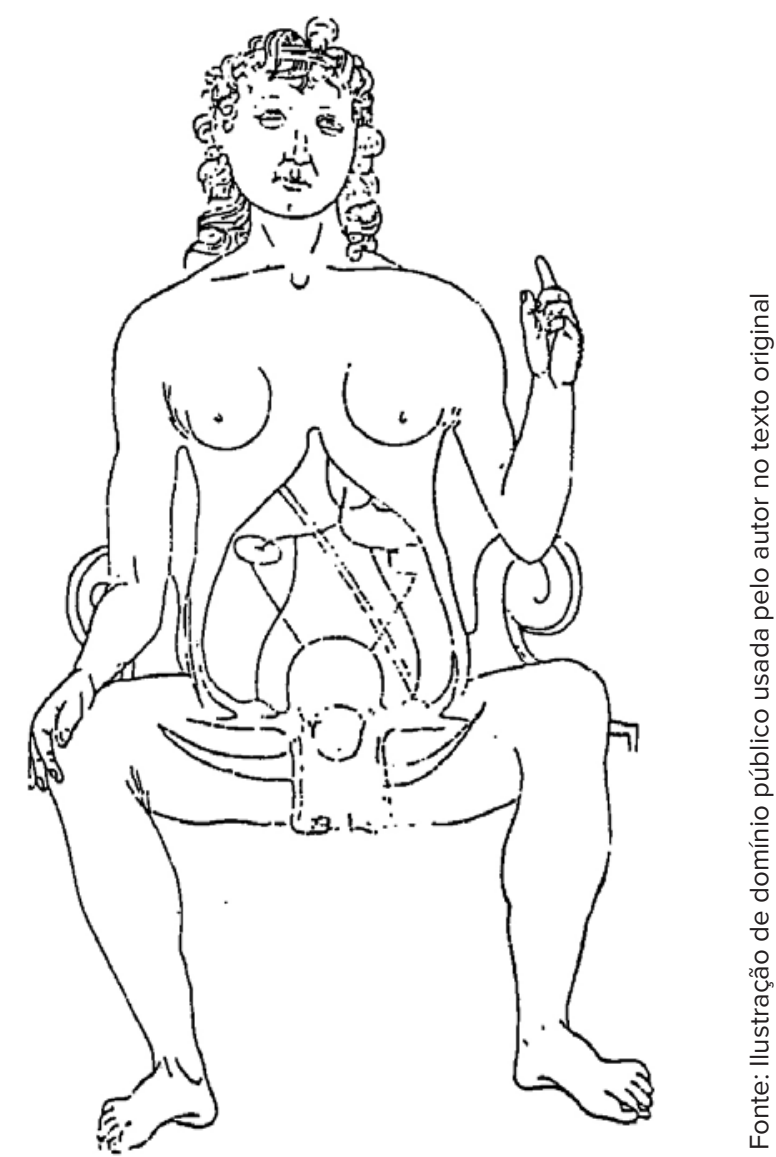

Figura 19: $O$ útero, Fascicolo di medicina.

(Veneza, 1493). 


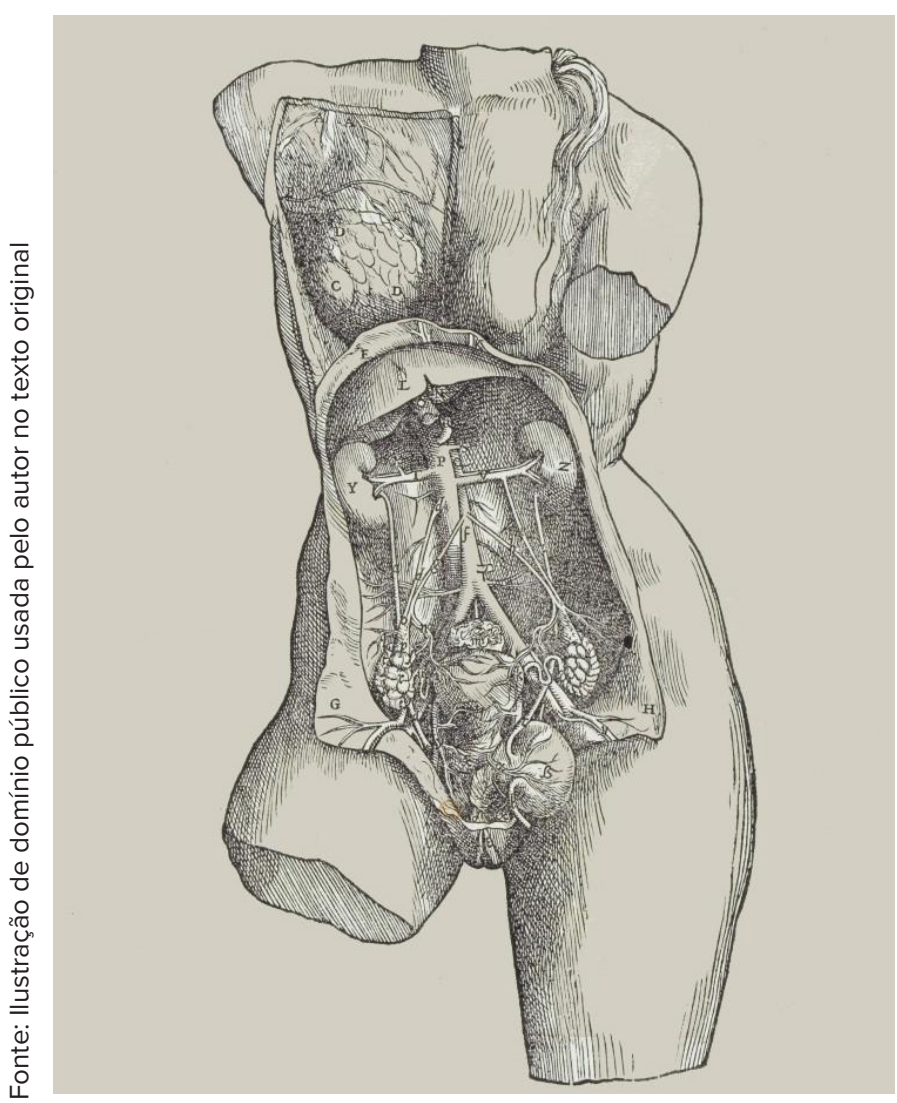

Figura 20: A antomia feminina, por Andre Vésale. De Humani Corporis Fabrica. (Basiléia, 1543)

algum revelam qual dos dois órgãos é colocado na frente do outro. $\mathrm{Na}$ verdade, essas ilustrações são inúteis se alguém acreditar que um livro de anatomia deve ensinar ao aluno onde encontrar o órgão retratado em um corpo humano real. Desnecessário dizer que as ilustraçóes de Vesálio são muito superiores aos outros neste quesito. Não só vemos claramente a posição dos órgãos e músculos relacionados uns aos outros, mas podemos até mesmo entender sua função. As ilustraçóes de Vesálio trouxeram, ainda durante o curso de sua vida, uma verdadeira revolução na Ciência. Nunca e em nenhum lugar da História os estudantes conseguiram aprender Anatomia de maneira táo comunicativa. Fotografias modernas dos mesmos músculos e órgãos não são tão claras, precisas e decisivas como as ilustraçôes de Vesálio.
Certamente, Vesálio não era fruto da perspectiva linear em si, no entanto, como nos ensina a História da Arte, a evolução da representação do corpo humano durante a Renascença foi uma das suas principais consequências indiretas. Antes de tudo, a perspectiva permitia representar o corpo humano de maneira diferente da figura frontal e plana (Figura 21). O resultado foi um súbito interesse nas complicadas contorçôes do que sobrou da escultura romana. Da mesma forma que, artistas começaram a considerar a imagem como uma "janela”, eles também foram incentivados a representar o corpo humano como uma “escultura”. Vesálio, engenhosamente, tirou partido dessas noçôes populares. Ele literalmente retirou a figura humana de pinturas venezianas contemporâneas e arrancou sua pele para expor os músculos e vísceras por ela escondidos. Até a época de Vesálio, existia um forte preconceito religioso contra a dissecação. Havia também uma tendência pedante de se lidar apenas com as teorias de Galeno. No entanto, o principal obstáculo ao progresso da Ciência foi a completa incapacidade de se representar adequadamente o que os cientistas viram nas raras dissecaçóes que podiam praticar, bem como a insuficiência da apresentação do conhecimento adquirido nos livros didáticos. Como se sabe, para todo estudante que se prepara para a Escola de Medicina e deve passar pelo duro teste de um exame prático o $\mathrm{MCAT}^{5}$ sobre Anatomia, nada se compara a uma boa ilustração em perspectiva. Nenhum texto, nem mesmo uma fotografia, pode substituí-la.

Artistas como Leonardo e Michelangelo abriram o caminho para Vesálio aplicar sua visão recém-adquirida sobre perspectiva no estudo minucioso do corpo humano, tanto por dentro quanto por fora. Desde o final do século XV, eram os artistas e não os médicos que possuíam o melhor conhecimento da anatomia 

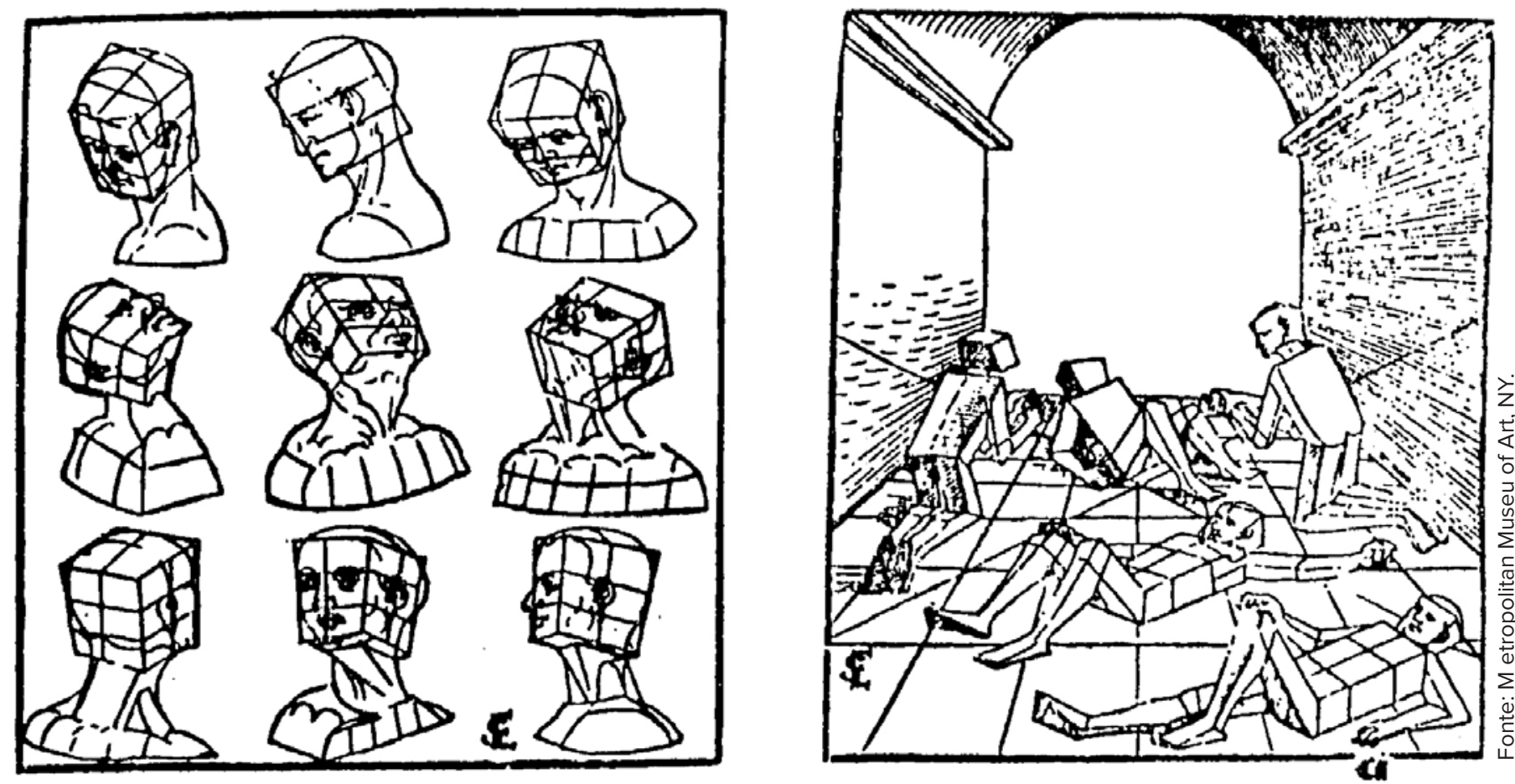

Figura 21: Erhard Schön, "Cabeças e torsos estereométricas em Unterweisung der proporzion und Stellung der Possen (Tratado sobre a proporção e a posição das posturas), 1538. Woodcut. (Metropolitan Museum of Art, NY.)

humana. Antes de Vesálio, esse assunto era, por assim dizer, monopólio do artista, e até hoje, raros são aqueles que acreditam que Vesálio poderia ter executado suas ilustraçôes ele mesmo. Elas são atribuídas, em geral, a um pintor chamado Kalchar e, às vezes, até mesmo ao grande Ticiano.

A redescoberta da perspectiva linear náo aconteceu muito antes da invençáo da imprensa na Europa. Essa é outra coincidência bizarra se pensarmos que a China imprimia já há muitos séculos. De qualquer maneira, a imprensa, combinada com a pintura em perspectiva, criou uma revolução na informação. Náo seria exagerado valorizar a importância do papel desempenhado pelo livro impresso e ilustrado - o tratado de Vesálio, por exemplo - na ascensão do Ocidente durante o século XVI. Agora era possível que mais pessoas não somente aprendessem sobre mais tópicos, mas aprendessem também a "ver" em perspectiva. Graças à divulgação pública de ilustraçôes em perspectiva, estaria, pelo menos teoricamente, ao alcance de qualquer um se tornar o próprio Leonardo da Vinci. Não seria surpreendente, nessas condiçóes que no espaço de apenas cem anos, o Ocidente tenha sido capaz de produzir um Galileu (coincidentemente um florentino), um Kepler, um Descartes, um Newton e um Lineu. Seria presunçoso da minha parte insinuar que esses grandes gênios da revolução científica ocidental devessem suas descobertas à perspectiva linear. No entanto, não se pode imaginar como eles poderiam ter realizado seu trabalho em um mundo em que ela não existisse. 


\section{Notas de fim:}

1. Sobre a "perspectiva" da pintura chinesa, ou melhor, o desenho esquemático e as representaçóes axonométricas usadas para retratar objetos em três dimensōes, veja Joseph Needham, Science and Civilization in China (Cambridge, Reino Unido, 1971), vol. IV, 3a parte, seçóes 28-29, pp. 104119). Convençóes similares, mas menos sistematicamente aplicadas, encontradas na arte islâmica foram estudadas por Donald F. Hill em The Book of Knowledge of Ingenious Mechanical Devices (Boston, 1974). Ambos Needham e Hill enfatizam, não sem razão, que as ilustraçôes usando projeção axonométrica ou isométrica promoveram o desenvolvimento de tecnologia (de fato, a maioria dos desenhos são deste tipo), porque elas náo apresentavam proporçôes deformadas. Eu poderia simplesmente afirmar que a perspectiva linear permite que o artista tenha uma visão muito mais global e que o desenho axonométrico é mais útil para representar uma parte de um todo. $\mathrm{O}$ desenho em perspectiva linear é superior quando se trata de mostrar os componentes de um conjunto. É possível que o desenho axonométrico tenha contribuído para que a China superasse o Ocidente no plano tecnológico durante a Idade Média, mas foi, certamente, a perspectiva linear que permitiu ao Ocidente avançar estágios da tecnologia e operar uma verdadeira revolução civil após o Renascimento.

2. No que diz respeito à noção de espaço concebida pelo pensamento ocidental e expressa tanto na História da Arte como na Ciência, ver Erwin Panolsky, "Perspectiva como Forma Simbólica e outros ensaios" (Lisboa, Ediçóes 70, 1999, precedido por “A Questão da Perspectiva, por Marisa Dalai
Emiliani; Paris: Editions de Minuit, 1976), 278p, As relaçóes entre o conceito de espaço, a música e a arquitetura na Idade Média é examinada por Fritz Winckel em "Sound Structures and Structures of Space: Music and Architecture", CULTURES, 1, (1974), pp. 143-202.

\section{Notas da traduçáo:}

3. Mammon no Novo Testamento é comumente pensado para significar dinheiro, material de riqueza, ou qualquer entidade que promete riqueza, e está associada com o ganancioso busca de ganhos. Em Mateus 6:24: "Ninguém pode servir a dois senhores, porque ou há de odiar um e amar o outro ou se dedicará a um e desprezará o outro. Você náo pode servir a Deus e a Mamom."

4. Em contabilidade, o Método das Partidas Dobradas, ou Método Veneziano, descrito pela primeira vez por Luca Pacioli no livro "Summa de Arithmetica, Geometria, Proportioni et Proportionalità" em 1494, é o sistema-padrão usado em empresas e outras organizaçóes para registrar transaçôes financeiras. Sua premissa é de que a condição financeira e os resultados das operaçóes de uma empresa ou organização são melhor representadas por diversas variáveis, chamadas contas, em que cada uma reflete um aspecto em particular do negócio como um valor monetário. Cada transação financeira é registrada na forma de entradas em pelo menos duas contas, nas quais o total de débitos deve ser igual ao total de créditos.

5. O Medical College Admission Test (MCAT) é um exame padronizado de múltipla escolha desenvolvido para avaliar a resolução de problemas, o pen-

Revista online do Departamento de Arquitetura e Urbanismo da Pontifícia Universidade Católica -

Puc-Rio - Rio de Janeiro Brasil

Ano 3 - N ${ }^{\circ} 5$ - ISSN 2446-7340 
samento crítico e o conhecimento dos conceitos e princípios básicos das Ciências natural, Comportamental e Social que são pré-requisitos para candidatos às escolas de Medicina nos Estados Unidos, Austrália, Canadá e Ilhas do Caribe.

\section{Agradecimentos:}

Agradeço a colaboração dos professores Antonio Sena e Maíra Machado Martins, nos apuros do francês e ao querido e saudoso, Professor Jorge Czajkowski, que em 1978, me forneceu uma cópia desse artigo que, mesmo depois de passados 40 anos, continua interessante, sem que nunca tenha sido traduzido. 